Luis Henrique Ishida

\title{
Estudo anatômico comparativo entre o retalho escapular e o retalho perfurante da artéria toracodorsal
}

Dissertação apresentada à Faculdade de Medicina da Universidade de São Paulo para obtenção do título de Mestre em Ciências

Área de concentração: Cirurgia Plástica Orientador: Dr. Julio Morais Besteiro

São Paulo

2006 


\section{Dados Internacionais de Catalogaçãa na Publicação (CIP)}

Preparada pela Bíblioteca da

Faculdade de Medicina da Universidade de São Paulo

Creprodução autorizada pelo autor

Ishida, Luis Henrique

Estudo anatômico comparativo entre o retalho escapular e retalho perfurante da artéria toracodorsal / Luis Henrique Ishida. - São Paulo, 2006.

Dissertação(mestrado)-Faculdade de Medicina da Universidade de São Paulo.

Departamento de Cirurgia.

Área de concentraçăo: Cirurgia Plástica.

Orientador: Julio Morais Besteiro.

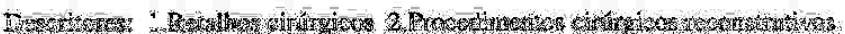

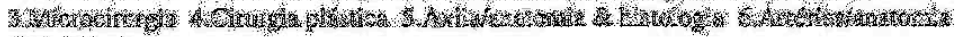

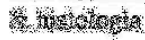

WRE 
Para minha esposa e meu filho, Adriana e Murilo. 
Agradecimentos 
A execução desta dissertação só foi possível graças à colaboração de diversas pessoas, a quem devo minha profunda gratidão, em especial:

Ao Dr. Jorge Ishida, meu pai, e maior orientador da minha vida pessoal e profissional.

À Araci Tino Ishida, minha mãe, pelo amor e carinho que sempre dedicou.

Ao Dr. Luiz Carlos Ishida, meu irmão, pelos sólidos ensinamentos em microcirurgia, orientação e amizade.

Ao Dr. Julio Morais Besteiro, meu orientador e professor, pelos profundos e constantes conhecimentos transmitidos e orientação da minha formação científica.

Ao Prof. Dr. Marcus Castro Ferreira, Professor Titular da Disciplina de Cirurgia Plástica da Faculdade de Medicina da Universidade de São Paulo, pelo inestimável apoio e pela oportunidade concedida para a realização desta tese.

Ao Prof. Dr. Arnaldo Valdir Zumiotti, Professor Titular da Disciplina de Ortopedia e Traumatologia da Faculdade de Medicina da Universidade de São Paulo, pelos ensinamentos e apoio na minha formação. 
Ao Dr. Alexandre Mendonça Munhoz, grande amigo e orientador de fundamental importância na minha vida científica, pelo incentivo que possibilitou a pesquisa com retalhos perfurantes.

Ao Dr. Fabio Busnardo, pela amizade sincera e valioso apoio desde o início das nossas pesquisas com retalhos perfurantes.

Ao Dr. Alexandre Piassi Passos, pela grande amizade e convivência profissional.

Ao Dr. José Carlos Marques Faria, pelo exemplo e conhecimentos transmitidos em microcirurgia.

Ao Dr. Teng Hsiang Wei, entusiasta dos retalhos perfurantes, pelo companheirismo e pelas longas discussões cirúrgicas.

Aos Prof. Dr. Rolf Gemperli, Dr. Paulo Tuma, Dr. Miguel Modolin, Prof. Dr. Nivaldo Alonso e Prof. Dr. Henri Friedhofer pelos valiosos conselhos e cuidados dispensados na minha formação como cirurgião plástico. 
Ao Dr. Eduardo Montag, pelo apoio e companheirismo presente tanto na minha vida científica como pessoal.

Ao Dr. Fábio Lopes Saito, pelo auxílio em dissecções, ilustrações e pela grande amizade.

Aos Drs. Hugo Nakamoto, Alberto Yoshikazu Okada, Ricardo Nani, Tatiana Moura, Gustavo Sturtz, Eduardo Gustavo Arruda, Leandro Pelarin pelas longas horas passadas no Serviço de Verificação de Óbitos para realização desta tese.

Aos residentes de cirurgia plástica, Hélio Ricardo Nogueira Alves, José Carlos, Walter Koiti Matsumoto, pelo auxílio nas dissecções anatômicas desta tese e de outros trabalhos.

À Sra. Magnólia Pires Miranda, minha querida sogra, pelo precioso auxílio na correção do texto.

À secretaria Edna Maria Rodrigues dos Santos, pela paciência e orientação nas etapas burocráticas da pós-graduação.

Aos técnicos do Serviço de Verificação de Óbitos pelo auxílio na preparação dos cadáveres utilizados nesta tese. 
À Ana Rosa Martins Horácio, Helga Darge, Joel Moreira, Leda Dotti Carneiro, Maria da Conceição Moreira, Maria Wanderléia Sampaio da Silva, Rejane Gomes Moreira, Suelen Serpa de Souza e Valderez Sola pelo prazeroso convívio no dia a dia.

A todos os membros da Disciplina de Cirurgia Plástica Professor da Faculdade de Medicina da Universidade de São Paulo, que tiveram participação direta ou indireta na produção desta tese. 


\section{Normalização adotada}

Esta tese está de acordo com as seguintes normas, em vigor no momento desta publicação:

Referências: adaptado de International Commitee of Medical Journals Editors (Vancouver).

Universidade de São Paulo. Faculdade de Medicina. Serviço de Biblioteca e Documentação. Guia de apresentação de dissertações, teses e monografias. Elaborado por Annelise Carneiro da Cunha, Maria Julia de A. L. Freddi, Maria F. Crestana, Marinalva de Souza Aragão, Suely Campos Cardoso, Valéria Vilhena. $2^{\underline{a}}$ ed. São Paulo: Serviço de Biblioteca e Documentação; 2005.

Abreviaturas dos títulos dos periódicos de acordo com List of Journals Indexed in the Index Medicus. 
Sumário 


\section{Sumário}

Lista de Abreviaturas

Lista de símbolos

Resumo

Summary

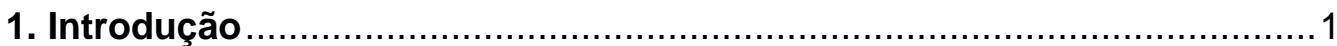

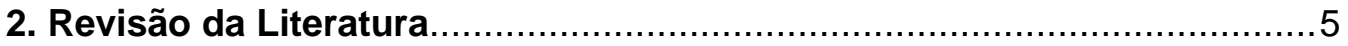

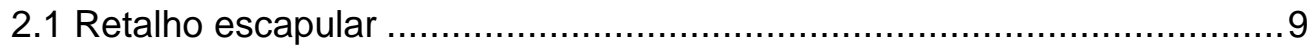

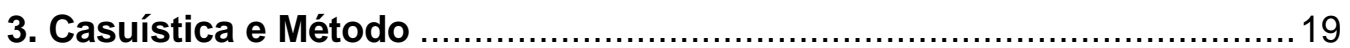

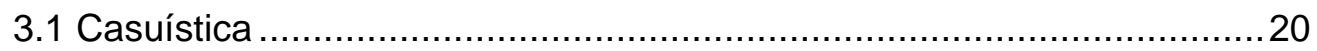

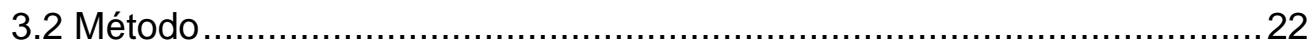

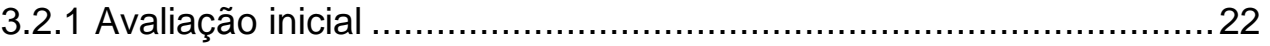

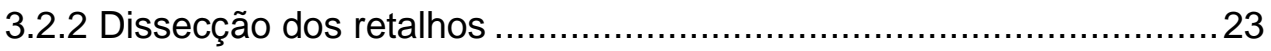

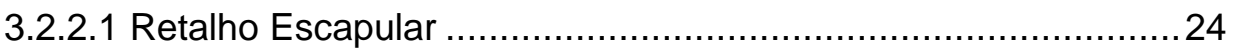

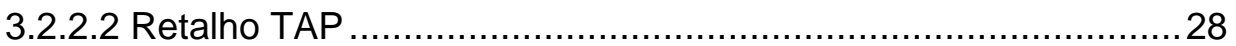

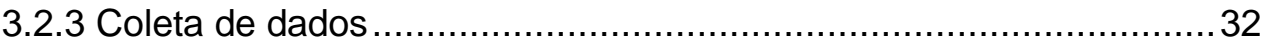

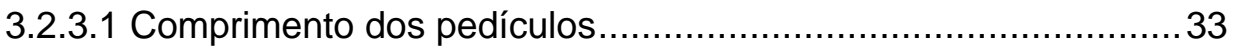

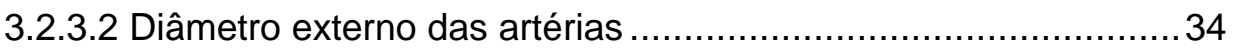

3.2.3.3 Diâmetro externo das veias....................................................... 35

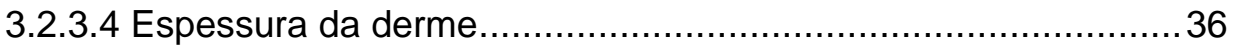

3.2.3.5 Espessura do tecido celular subcutâneo ................................. 37

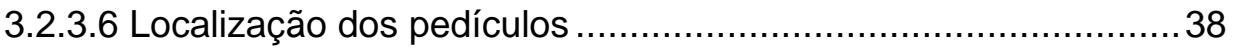

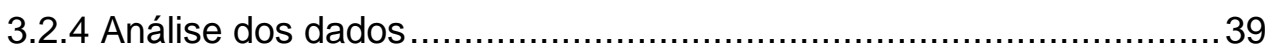




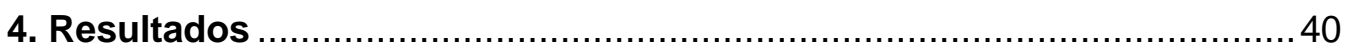

4.1 Comprimento dos pedículos ..................................................... 41

4.2 Diâmetro externo das artérias ........................................................... 43

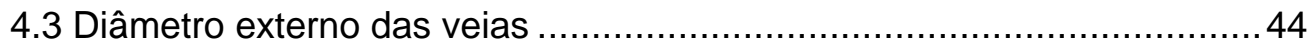

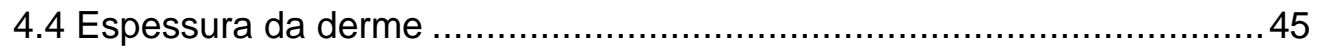

4.5 Espessura do tecido celular subcutâneo .......................................... 46

4.6 Localização dos pedículos .............................................................. 48

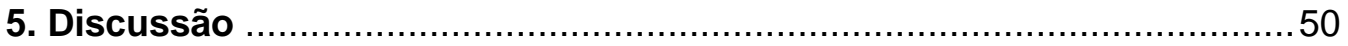

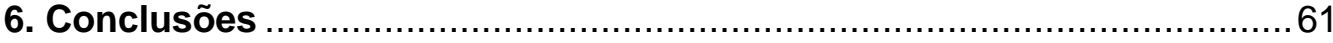

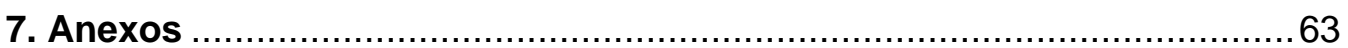

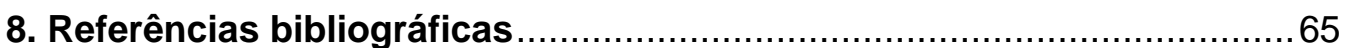


Lista de Abreviaturas 


\title{
LISTA DE ABREVIATURAS
}

\author{
a. artéria \\ ABNT Associação Brasileira de Normas Técnicas \\ Apud citado por \\ DIEP perfurante da artéria epigástrica inferior \\ Dr. Doutor \\ Drs. Doutores \\ Ed. edição \\ et al e outros
}

FIAA Federação Internacional de Associações de Anatomistas

Fig. figura

FMUSP Faculdade de Medicina da Universidade de São Paulo

m. músculo

Prof. Professor

p. página

Sra. Senhora

SVO-C Serviço de Verificação de Óbitos da Capital

TAP perfurante da artéria toracodorsal

USP Universidade de São Paulo

v. veia 
Lista de Símbolos 


\section{LISTA DE SÍMBOLOS}

\begin{tabular}{ll} 
\pm & mais ou menos \\
$\%$ & porcentagem \\
\hline & graus \\
$=$ & igual \\
$\mathrm{cm}$ & centímetro \\
$\mathrm{cm}^{2}$ & centímetro quadrado \\
$\mathrm{kg}$ & kilograma \\
$\mathrm{m}$ & metro \\
$\mathrm{mHz}$ & megahertz \\
$\mathrm{mm}$ & milímetro \\
$\mathrm{p}$ & nível de significância estatística \\
$\mathrm{x}$ & por \\
$\circledR$ & marca registrada
\end{tabular}


Resumo 
Ishida, Luis H. Estudo anatômico comparativo entre o retalho escapular e o retalho perfurante da artéria toracodorsal. São Paulo, 2006. 73 p. Dissertação (mestrado) - Faculdade de Medicina da Universidade de São Paulo. Disciplina de Cirurgia Plástica

Desde a primeira descrição do retalho perfurante de artéria toracodorsal (TAP), sua indicação tem sido questionada por se tratar de um retalho de características semelhantes aos retalhos fasciocutâneos escapulares baseados na artéria circunflexa escapular, que são bem conhecidos e reprodutíveis. Este estudo visa comparar características anatômicas destes dois retalhos, distinguindo-os para uma melhor indicação. Adicionalmente o estudo visa estudar o posicionamento do pedículo perfurante do retalho TAP. Vinte e um pares de retalhos (TAP e escapular) foram dissecados simultaneamente em cadáveres frescos. Os músculos latíssimo do dorso e redondo maior foram seccionados e os dois retalhos foram retirados em peça única. O comprimento do pedículo, diâmetro externo da artéria e da veia, espessura da derme e espessura do tecido celular subcutâneo de ambos os retalhos foram avaliados e comparados de forma pareada. A localização dos pedículos dos retalhos foi avaliada em ambos os retalhos. Os dados obtidos foram analisados estatisticamente através do teste $t$ de Student. O retalho TAP apresentou um pedículo com média de 16,95 cm de comprimento, sendo $50 \%$ maior que o do retalho escapular $(p<0,05)$. A espessura média da derme foi $2,12 \mathrm{~mm}$, sendo $42 \%$ mais fina do que a do retalho escapular; e a do tecido subcutâneo foi $1,37 \mathrm{~cm}$, sendo $28 \%$ mais 
fina do que a do retalho escapular $(p<0,05)$. O pedículo do retalho TAP apresentou artéria com diâmetro médio de 3,14 mm e veia com diâmetro médio de $3,03 \mathrm{~mm}$, enquanto o pedículo do retalho escapular apresentou artéria com diâmetro médio de 3,33 mm e veia com diâmetro médio de 2,95 mm, ambos sem diferenças estatísticas. Nas dissecções estudadas, todos os pedículos dos retalhos escapulares se localizavam no "espaço triangular". Já a localização dos pedículos perfurantes do retalho TAP não apresentou nenhum parâmetro constante. O estudo demonstrou que, apesar de se localizarem em sítios anatômicos adjacentes, o retalho TAP possui um pedículo mais longo e sua pele é mais fina do que o retalho escapular. Por outro lado, o posicionamento do pedículo do retalho escapular é constante, enquanto o pedículo perfurante do retalho TAP possui localização variável. 
Summary 
Ishida, Luis H. Comparative anatomical study between the thoracodorsal artery perforator flap and the scapular flap. São Paulo, 2006. 73 p. Dissertation (mestrado) - Faculdade de Medicina da Universidade de São Paulo. Disciplina de Cirurgia Plástica.

Indication of the thoracodorsal artery perforator (TAP) flap has been questioned because its characteristics are similar to those of scapular flaps based on the scapular circumflex artery. The scope of this study is to compare the anatomic features of these two flaps, differentiating them for a better indication. Twenty-one pairs of flaps (TAP and scapular) were dissected simultaneously in fresh cadavers. The length of the pedicles, thickness of the arteries and veins of the pedicles, and the thickness of the dermis and subcutaneous tissue of the flaps were assessed and compared. The position of the pedicles of both flaps was evaluated. The average length of the TAP flap pedicle was $16.95 \mathrm{~cm}$, and it was $50 \%$ longer than the scapular flap $(p<0.05)$. The mean thickness of the dermis was $2.12 \mathrm{~mm}$ and of the subcutaneous tissue $1.37 \mathrm{~cm}$, respectively $42 \%$ and $28 \%$ thinner than the scapular flaps $(p<0.05)$. No significant difference was evident between the thicknesses of the pedicles. The TAP arterial pedicle was $3.14 \mathrm{~mm}$ and the venous one $3.03 \mathrm{~mm}$. The scapular flap demonstrated a $3.33 \mathrm{~mm}$ arterial pedicle and $2.95 \mathrm{~mm}$ for the venous one. The evaluation of the position of the pedicle of the scapular flap was constant; on the other hand, the perforator pedicle of the TAP flap did not show any constant anatomical parameter. The study revealed that although the TAP flap and the scapular flap lie in 
adjacent anatomical areas, the TAP flap has a longer pedicle and a thinner skin; their vascular pedicles have similar thickness; though the position of the thoracodorsal perforator pedicle is variable, when compared with the scapular flap. 
1. Introdução 
A região dorsal do tronco tem sido uma das áreas doadoras preferenciais de retalhos em cirurgias reconstrutivas. A região possui diversas características favoráveis para a dissecção de retalhos como: possuir plexo vascular constante; permitir a dissecção de retalhos com pedículos longos; localizar-se em área coberta por vestimentas habituais; possuir pele de espessura relativamente fina e geralmente desprovida de pêlos (Dos Santos, 1980; Gilbert; Teot, 1982; Guerra et al, 2004; Hamdi et al, 2004).

Dentre os retalhos da região, o retalho miocutâneo de músculo latíssimo do dorso tem sido utilizado rotineiramente por todo o mundo. Apesar de ser um dos retalhos mais seguros utilizados na cirurgia reconstrutiva, sua espessura é grande, dificultando reconstruções superficiais cutâneas, como nas extremidades ou reconstruções faciais (Bostwick et al, 1979; Tobin et al, 1981; Pensler; Parry, 1986; Guerra et al, 2004).

Koshima e Soeda (1989) introduziram o conceito de retalhos perfurantes, no qual os pedículos perfurantes de retalhos miocutâneos são totalmente dissecados através da musculatura local. Tal dissecção preserva a anatomia muscular e nervosa, resultando em um menor déficit funcional (Blondeel et al, 1997). Além disso, estes retalhos possuem pedículos mais longos do que os dos retalhos miocutâneos, pois todo o comprimento intramuscular é adicionado ao comprimento total do pedículo. A espessura destes retalhos habitualmente é mais delgada, pois não há a presença da musculatura (Kroll; Rosenfield, 1988; Koshima et al, 1993). 
Diversos retalhos perfurantes foram descritos durante a década de 90, Angrigiani et al (1995), com o objetivo de diminuir a morbidade da área doadora do retalho latíssimo do dorso, propuseram sua dissecção com preservação total do músculo e do nervo toracodorsal. Este retalho foi denominado retalho perfurante da artéria toracodorsal (TAP). O pedículo deste retalho é longo, pois há um aumento no comprimento do pedículo, resultante da sua dissecção através do músculo latíssimo do dorso. A porção cutânea do retalho é delgada, favorável à cobertura de regiões de pele fina, como nas extremidades. Sua espessura fina confere maleabilidade em reconstruções tridimensionais, em que há necessidade de modelagem dos retalhos, como nas reconstruções de cabeça e pescoço (Angrigiani et al, 1995; Hamdi et al, 2004; Guerra et al, 2004; Thomas et al, 2005).

Adjacente à área doadora do retalho TAP, encontram-se os retalhos fasciocutâneos derivados do pedículo circunflexo escapular, como o retalho escapular e paraescapular. Estes últimos possuem como principais vantagens o pedículo longo, espessura fina e baixa morbidade da área doadora. Tais retalhos têm sido utilizados rotineiramente, e sua eficácia está bem estabelecida (Dos Santos, 1980; Gilbert; Teot, 1982; Nassif et al, 1982; Thoma; Heddle, 1990; Coleman et al, 1991).

Como as características tanto do retalho escapular como do retalho perfurante toracodorsal são semelhantes, a indicação de utilização de um ou de outro não está clara na literatura médica. Nenhum estudo comparativo entre os dois retalhos foi encontrado em nossa revisão bibliográfica. 


\subsection{Objetivos}

O presente estudo tem como objetivo a avaliação das características anatômicas do retalho perfurante da artéria toracodorsal comparando-as com as do retalho escapular através de dissecção em cadáveres frescos, distinguindo-os para uma melhor indicação cirúrgica.

Os itens a serem avaliados comparativamente em ambos os retalhos são:

I. Comprimento total dos pedículos do retalho escapular e do retalho TAP.

II. Diâmetro externo dos pedículos arteriais do retalho escapular e do retalho TAP na sua origem.

III. Diâmetro externo dos pedículos venosos do retalho escapular e do retalho TAP na sua origem.

IV. Espessura da derme do retalho escapular e do retalho TAP.

V. Espessura do tecido celular subcutâneo do retalho escapular e do retalho TAP.

VI. Localização do pedículo vascular do retalho escapular e do retalho TAP. 
2. Revisão da Literatura 
Manchot em 1889 apud Taylor (1990b), em estudos anatômicos da vascularização cutânea, descreveu o primeiro relato da presença de vasos septocutâneos, de importância fundamental no desenvolvimento dos retalhos fasciocutâneos. Neste mesmo estudo, o autor, ao dividir o dorso em territórios vasculares cutâneos, já demonstrou a presença de um território cutâneo escapular, denominado "8", e um toracodorsal, denominado "4" (fig. 1).

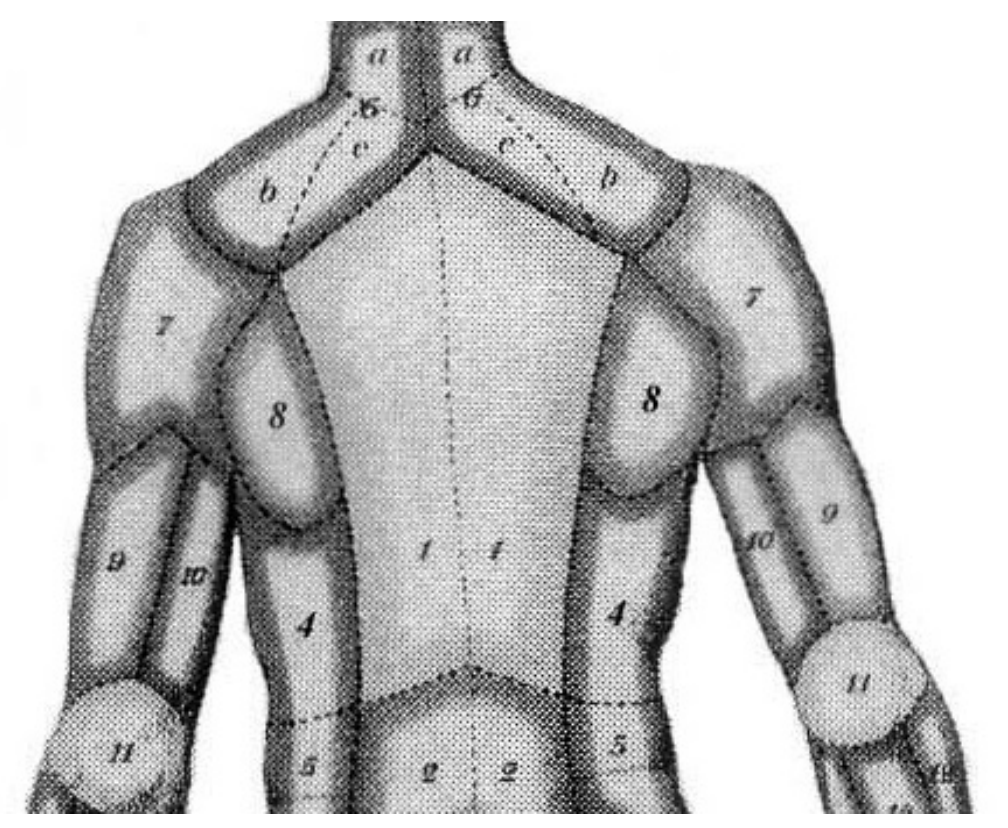

Figura 1. Detalhe da ilustração de Manchot (1889) apud Taylor (1990b) do dorso humano com delimitação de territórios vasculares cutâneos. $O$ território denominado "8" é irrigado pela a. circunflexa escapular e o território denominado "4" é irrigado pela a. toracodorsal. Extraído de Taylor (1990b). 
Salmon (1936) apud Taylor (1990b), num estudo anatômico com meios de contraste radiopacos, demonstrou a importância dos vasos septocutâneos na distribuição sanguínea nos territórios cutâneos. Assim como Manchot, o autor delimitou dois territórios vasculares cutâneos na região dorsal, denominados "9" e "23", que representariam os territórios irrigados pela artéria circunflexa escapular e pela artéria toracodorsal respectivamente (fig. 2).

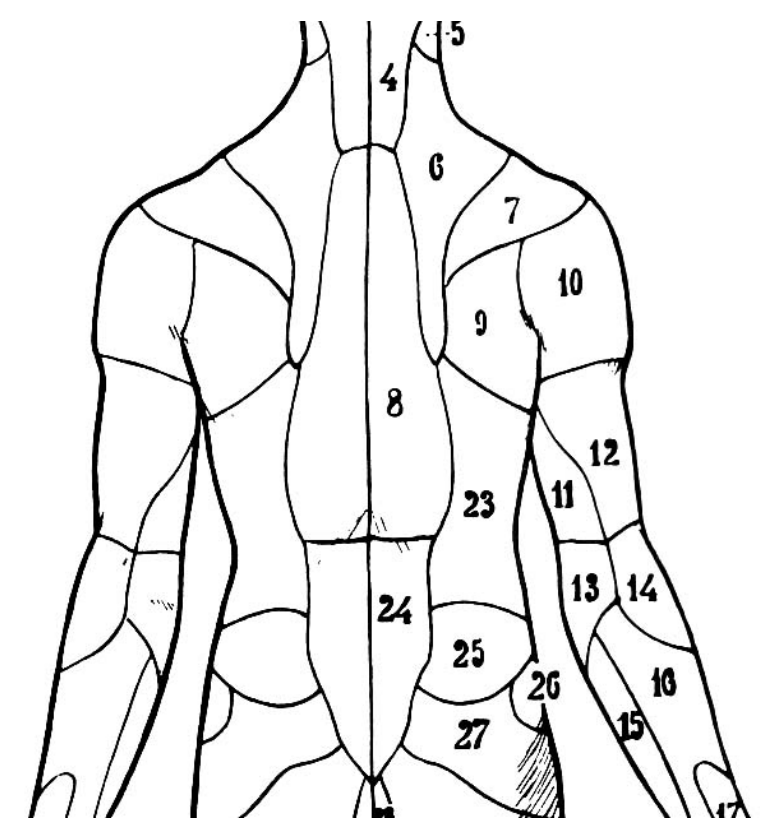

Figura 2. Detalhe da ilustração de Salmon (1936) apud Taylor (1990b) do dorso humano com delimitação de territórios vasculares cutâneos. $O$ território denominado "9" é irrigado pela a. circunflexa escapular e o território denominado "23" é irrigado pela a. toracodorsal. Extraído de Taylor (1990b). 
Rowsell et al (1984) realizaram um estudo anatômico do sistema arterial subescapular-toracodorsal em 100 cadáveres. Neste estudo, a artéria circunflexa escapular, pedículo principal do retalho escapular, foi ramo da artéria subescapular em $97 \%$ das dissecções. A artéria toracodorsal, pedículo do retalho TAP, foi ramo da a. subescapular em 94\% das dissecções. No restante das dissecções, as artérias toracodorsal e circunflexa escapular eram ramos diretos da a. axilar. Portanto, na variação anatômica mais comumente encontrada, a artéria subescapular de divide em artéria circunflexa escapular e artéria toracodorsal, pedículos dos dois retalhos do presente estudo.

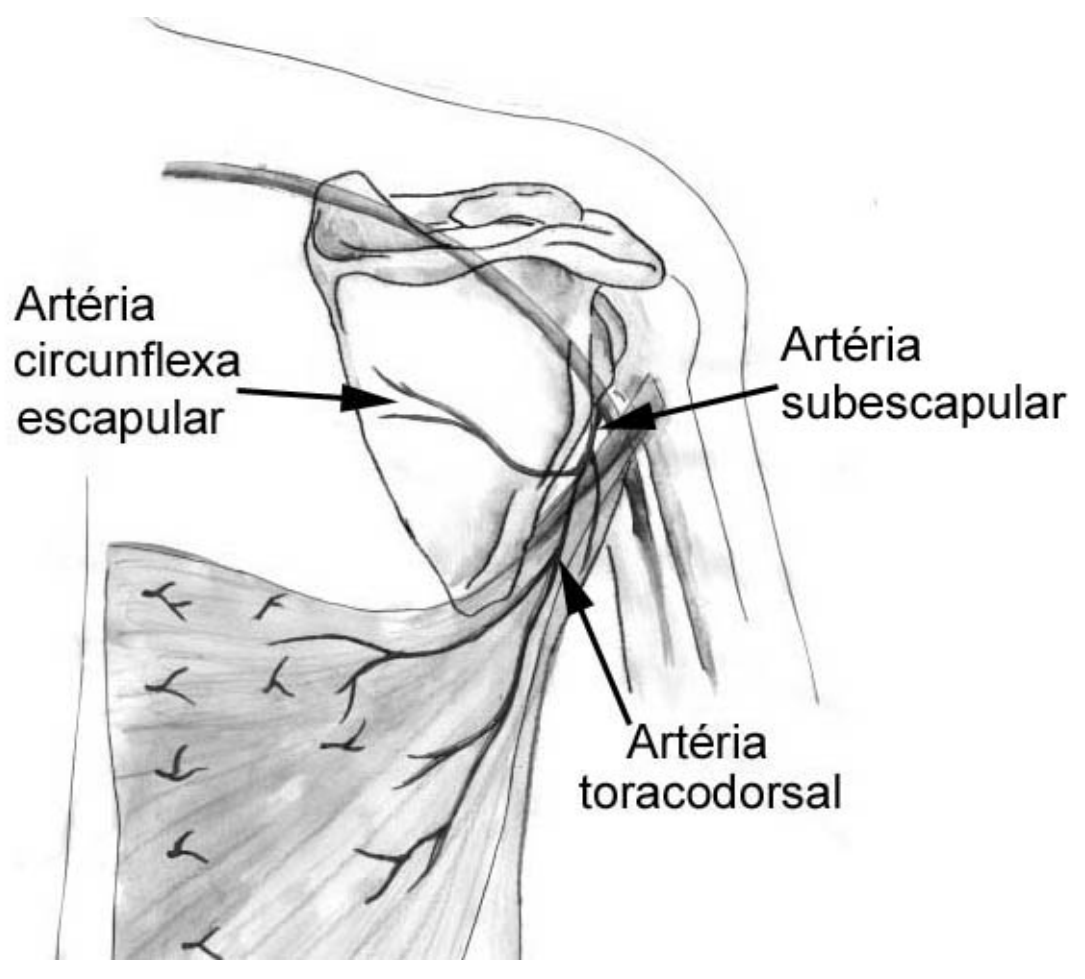

Figura 3. llustração representativa da distribuição anatômica mais comum da a. subescapular e suas divisões: acima, a a. circunflexa escapular, pedículo principal do retalho escapular; e, abaixo, a a. toracodorsal, pedículo principal do retalho TAP. 


\subsection{Retalho escapular}

O desenvolvimento do retalho escapular só foi possível devido a estudos que demonstraram a importância da fáscia muscular na distribuição do fluxo sanguíneo. Esser em 1918 apud Bonatto et al (2002), e Gilles em 1920 apud Bonatto et al (2002) foram os primeiros autores a propor a inclusão da fáscia muscular em seus retalhos para sua melhor vascularização.

Lang, em 1962, apud Daniel e Kerrigan (1990) e Schäfer, em 1975, apud Daniel e Kerrigan (1990) descreveram a anatomia detalhada da vascularização das fáscia musculares, distinguindo três plexos distintos: o fascial, o sub-fascial e o pré-fascial. O plexo pré-fascial foi considerado como o mais importante na distribuição do fluxo sanguíneo.

Dos Santos $(1980,1984)$ em um estudo de dissecção em 35 cadáveres, descreveu a presença constante do pedículo circunflexo escapular e seu território cutâneo. A autora propôs a utilização do mesmo no retalho escapular e apresentou um caso em que o retalho foi usado na sua forma microcirúrgica. As vantagens deste retalho seriam: a anatomia constante do seu pedículo vascular, fácil dissecção cirúrgica e possibilidade de fechamento primária da área doadora. 
Pontén, em 1981, demonstrou clinicamente maior taxa de sucesso em reparações cutâneas do membro inferior quando incluía a fáscia muscular nos retalhos cutâneos. Este foi o trabalho original que definiu os retalhos fasciocutâneos.

Barwick et al (1982) publicaram uma revisão da anatomia e técnica de dissecção do retalho escapular. Os autores descreveram a característica fasciocutânea da vascularização do retalho; e enfatizaram a localização constante do pedículo vascular no denominado "espaço triangular", compreendido entre os músculos subescapular e redondo menor superiormente, músculo redondo maior inferiormente, e cabeça longa do músculo tríceps lateralmente.

Gilbert e Teot (1982), numa revisão anatômica sobre o retalho escapular, sugeriram a dissecção retrógrada do mesmo, da porção medial para a lateral. Caracterizaram como suas principais qualidades: pele fina e sem pilificação, pedículo longo e constante, e facilidade técnica de dissecção. Citaram como principais limitações do retalho suas pequenas dimensões e cicatriz inestética resultante.

Nassif et al (1982) realizaram um estudo anatômico em 20 cadáveres, no qual descreveram a presença constante de um ramo descendente derivado da artéria circunflexa escapular. Tal pedículo possui um trajeto vertical, irrigando o denominado retalho paraescapular, que se localiza próximo à margem lateral da escápula. O posicionamento deste retalho é vertical, com seu limite superior no "espaço triangular", podendo se estender inferiormente por até 25 a $30 \mathrm{~cm}$. 
Koshima et al (1985) demonstraram, em um caso clínico, a possibilidade de associação dos retalhos escapular e paraescapular num mesmo pedículo. O retalho foi utilizado para cobertura de um defeito extenso de membro inferior e media $30 \times 13 \mathrm{~cm}$, o que tornou necessária a enxertia de pele na área doadora.

Swartz et al (1986) descreveram a possibilidade de associação de um segmento ósseo da margem lateral da escápula ao retalho escapular. Este segmento pode ter até 10 a $14 \mathrm{~cm}$ de comprimento com uma largura de 3 $\mathrm{cm}$ e espessura de $1,5 \mathrm{~cm}$. Os autores apresentaram uma série de 26 casos sem perdas do retalho ou morbidade significativa da área doadora.

Granick et al (1986) associaram outros retalhos, além dos ósseos, aos retalhos escapulares. Foram utilizados o músculo latíssimo do dorso e o músculo serrátil anterior irrigados pela artéria subescapular.

Thoma et al (1990) descreveram uma série de retalhos escapulares dissecados de forma estendida, chegando a ultrapassar a linha média posterior. O maior retalho desta série media $39 \times 10 \mathrm{~cm}$.

Maruyama (1991) propôs a utilização do ramo ascendente da a. circunflexa escapular como pedículo de um retalho dorsal para tratamento de retrações cicatriciais de queimaduras axilares. 


\subsection{Retalho TAP}

A história do desenvolvimento do retalho TAP se iniciou com a descrição do retalho do músculo latíssimo do dorso por Tanzini em 1906 apud McCraw (1980). O autor utilizou este retalho associado a sua porção cutânea irrigada por vasos perfurantes provenientes deste músculo em reconstruções mamárias após mastectomias radicais. Esta foi a primeira descrição de um retalho miocutâneo na literatura científica. Infelizmente, naquela época, tal relato não levou ao desenvolvimento dos retalhos miocutâneos. Somente no final da década de 70 , houve o reconhecimento geral da importância do retalho de m. latíssimo do dorso e dos retalhos miocutâneos em geral (Maxwell, 1980).

Baudet et al (1976) utilizaram um retalho cutâneo axilar baseado em ramos cutâneos diretos do pedículo toracodorsal. Tais ramos possuem uma localização septocutânea, entre a margem lateral do m. latíssimo do dorso e o m. serrátil anterior. Este retalho não se tornou popular naquele momento, principalmente devido à sua variabilidade anatômica (Taylor e Daniel, 1975). Somente após o desenvolvimento dos retalhos perfurantes, quase três décadas depois, houve novamente interesse por este retalho (Kim, 2005). 
No final da década de 70 , houve o estabelecimento da idéia inicial de Tanzini, seguido de diversas publicações que consagraram o retalho miocutâneo do m. latíssimo do dorso como um dos mais populares utilizados na cirurgia reparadora (Olivari, 1976; Schneider et al, 1977; Muhlbauer; Olbrisch, 1977; Boswick et al, 1978; Maxwell et al, 1978, Quillen et al, 1978). Variações cirúrgicas do retalho de miocutâneo do m. latíssimo do dorso surgiram visando um aprimoramento estético e funcional das reconstruções. Tobin et al (1981) descreveram a utilização do retalho bipartido de m. latíssimo do dorso, com preservação de uma porção funcional de músculo, e conseqüentemente minimizando a seqüela da área doadora.

Rowsell et al (1986) realizaram um estudo anatômico em 13 cadáveres, no qual demonstram a divisão do pedículo toracodorsal em um ramo lateral e um ramo horizontal (fig. 4). Esta anatomia possibilitaria o planejamento de retalhos baseados em somente um dos dois ramos, resultando em retalhos mais delgados e com maior preservação funcional. 


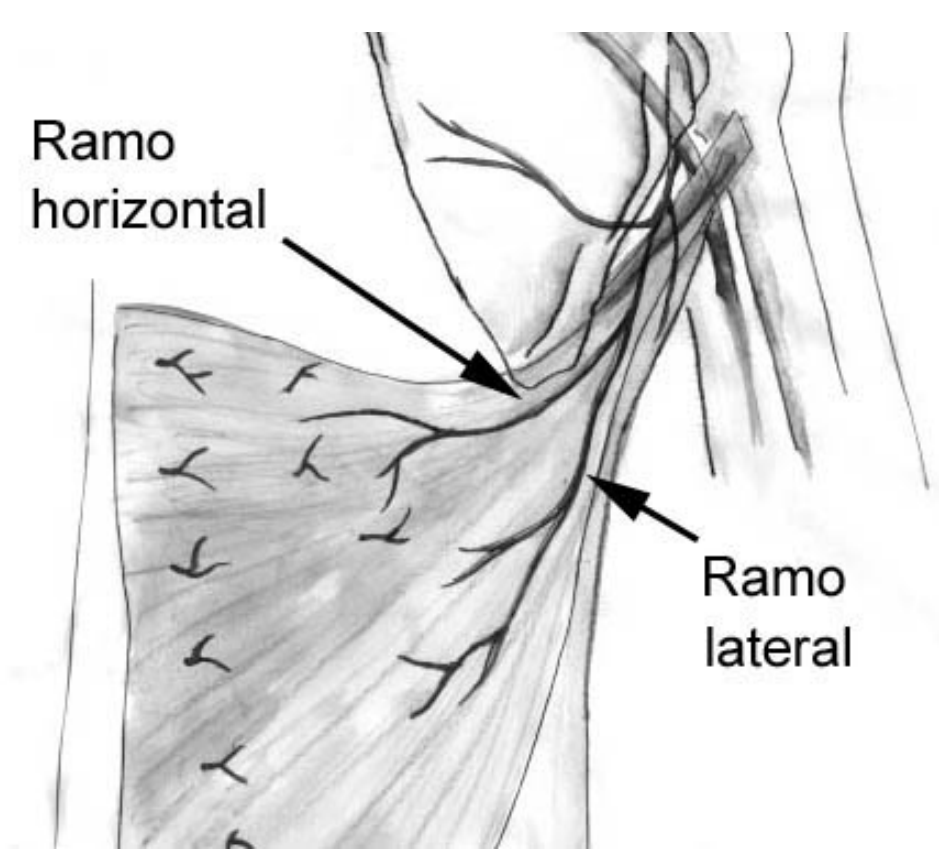

Figura 4. llustração representativa da a. toracodorsal e suas divisões: acima, o ramo horizontal; e, abaixo, o ramo lateral, pedículo principal do retalho TAP.

Em 1989, Hayashi et al. propuseram a transferência do retalho miocutâneo m. latíssimo do dorso com somente um pequeno segmento de músculo, acompanhado por uma unidade fasciocutânea associada, irrigada pelo plexo fascial proveniente de vasos perfurantes musculares. Segundo os autores, a pequena porção de músculo traria grande vascularização preenchendo defeitos mais profundos do leito receptor, enquanto a porção menos espessa - fasciocutânea - seria utilizada para refino estético na cobertura do defeito. 
A evolução da preservação muscular dos retalhos miocutâneos culminou na preservação total do músculo através de uma dissecção de um ou mais pedículos perfurantes por toda extensão intramuscular. Associada a esta dissecção, o nervo motor que habitualmente acompanha o pedículo vascular seria preservado através de uma dissecção cuidadosa. Este novo tipo de retalho foi denominado retalho perfurante (Koshima; Soeda, 1989; Koshima et al, 1993, Angrigiani et al, 1995).

Kroll e Rosenfield (1988) publicaram o primeiro trabalho a descrever retalhos irrigados exclusivamente em pedículos perfurantes. Os autores utilizaram retalhos baseados em vasos perfurantes paraespinais e parassacrais para fechamento de defeitos lombares baixos. Apesar de estes retalhos dependerem exclusivamente dos pedículos perfurantes, não havia dissecção intramuscular dos mesmos.

Koshima e Soeda (1989) descreveram a utilização do retalho miocutâneo do reto abdominal com preservação total da musculatura, baseando-se numa dissecção intramuscular extensa dos vasos perfurantes. Esta foi a primeira publicação a preconizar tal dissecção, que posteriormente se tornou a característica fundamental dos retalhos perfurantes (Blondeel et al, 1997). 
Angrigiani et al (1995) descreveram a possibilidade de dissecção de um retalho cutâneo do território do músculo latíssimo do dorso baseado exclusivamente em vasos perfurantes da artéria toracodorsal. Os autores utilizaram, preferencialmente o ramo descendente da artéria toracodorsal, posicionando a ilha cutânea longitudinalmente. Este retalho preserva totalmente o músculo latíssimo do dorso e sua inervação. Possui grande potencial de utilização como retalho local ou para transferência microcirúrgica. Nesta publicação inicial, os autores o denominam retalho musculocutâneo do m. latíssimo do dorso sem músculo.

Spinelli et al (1996) publicaram um estudo em que supõem que o retalho TAP teria uma ilha de pele semelhante àquela do retalho miocutâneo do m. latíssimo do dorso, porém com um pedículo mais longo. Neste trabalho, os autores classificam erroneamente o retalho como fasciocutâneo (Heitmann et al, 2003).

Koshima et al (1999) propuseram a utilização do pedículo vascular do retalho TAP em revascularizações de membros associadas à perda cutânea. Nestes procedimentos os autores utilizam a artéria e veia toracodorsal como enxertos vasculares restabelecendo o fluxo sanguíneo prévio.

Kim et al (2001) demonstraram a possibilidade de adelgaçamento do retalho TAP através de ressecção do tecido celular subcutâneo sob visão direta. Tal manobra seria indicada em coberturas cutâneas de defeitos rasos ou superficiais. 
Heitmann et al (2003) realizaram um estudo anatômico com 20 cadáveres e demonstraram que $56 \%$ dos pedículos perfurantes eram originários do ramo lateral da artéria toracodorsal e $44 \%$ eram provenientes do ramo horizontal da mesma. Apesar de haver a possibilidade de utilização do ramo horizontal como pedículo do retalho, os autores sugeriram a utilização preferencial do ramo lateral devido ao melhor posicionamento de sua ilha cutânea.

Chen et al (2004) preconizaram a utilização do retalho TAP como retalho de escolha para reconstruções de extremidades, pois possui espessura fina e compatível com o defeito; além de possuir um pedículo longo que pode alcançar os vasos receptores em defeitos irradiados ou gravemente traumatizados.

Hamdi et al (2004) propuseram a utilização do retalho TAP pediculado para reconstruções de quadrantectomias mamárias. Os autores citaram como principais vantagens: pedículo longo; pequena morbidade da área doadora; bom posicionamento da cicatriz resultante e pequena incidência de complicações. 
Thomas et al (2005) realizaram um estudo anatômico em 15 cadáveres frescos para avaliação do tamanho potencial do retalho TAP, baseado na sua anatomia vascular. Os autores injetaram uma solução de óxido de chumbo e gelatina no pedículo arterial dos retalhos e avaliaram a área vascularizada através de radiografias. Os autores concluíram que uma área de aproximadamente $600 \mathrm{~cm}^{2}$ pode ser irrigada por um pedículo perfurante deste retalho.

Kim (2005) descreveu as diferenças anatômicas do retalho TAP e do retalho toracodorsal descrito por Baudet et al (1976). Apesar de os dois retalhos possuírem praticamente o mesmo território cutâneo, o retalho TAP possui uma dissecção mais trabalhosa, devido ao seu trajeto intramuscular; porém possui um pedículo mais longo. Já o retalho toracodorsal é tecnicamente mais fácil de dissecar, porém possui pedículo mais curto. Os dois retalhos teriam morbidade semelhante, pois preservam a musculatura e inervação local. 
3. Casuística e Método 


\subsection{Casuística}

O presente estudo foi realizado, prospectivamente, no Sistema de Verificação de Óbitos da Capital (SVO-C). A amostra do estudo foi constituída por cadáveres em investigação da "causa mortis".

Foram realizadas dissecções anatômicas em 15 cadáveres frescos não formolizados, com menos de 24 horas de óbito. O retalho escapular e TAP correspondente ipsilateral foram dissecados. Em seis cadáveres a dissecção foi realizada bilateralmente, e nos nove cadáveres restantes a dissecção foi realizada unilateralmente, totalizando 21 pares de retalhos.

Considerou-se como critério de exclusão para utilização do cadáver, antecedentes ou sinais de cirurgias prévias na região dorsal ou lateral do tronco. Foram estudados dois cadáveres do sexo feminino, nos quais foram dissecados três pares de retalhos, e 11 cadáveres masculinos, nos quais foram dissecados 18 pares de retalhos. A idade variou de 30 a 80 anos com média de 52,5 $\pm 14,95$ anos. O peso variou de 45 a $90 \mathrm{~kg}$, com média de $70,6 \pm 13,8 \mathrm{~kg}$. A altura variou de 1,60 a $1,90 \mathrm{~m}$, com média de $1,73 \pm 0,09$ m.

O estudo foi aprovado pelo Comitê de Ética e Pesquisa do Hospital das Clínicas da FMUSP (anexo) e as dissecções seguiram as normas estabelecidas pelo SVO-C. 
Foi utilizada a nomenclatura proposta pela Sociedade Brasileira de Anatomia (2001) através da Terminologia Anatômica, que define os termos anatômicos em português, baseado nos termos originais em latim. Esta terminologia reflete o consenso da Comissão Federativa da Terminologia Anatômica e de 56 associações que integram a Federação Internacional de Associações de Anatomistas (FIAA), a única entidade internacional que representa todos os aspectos da anatomia. 


\subsection{Método}

\subsubsection{Avaliação inicial}

Primeiramente foram coletados os dados gerais dos cadáveres: sexo, idade, altura e peso. O prontuário médico foi avaliado em busca de dados referentes à antecedentes pessoais, comorbidades e "causa mortis". Foi realizado um exame de todo tronco à procura de patologias ou sinais de cirurgias prévias. De acordo com os dados obtidos, os cadáveres foram incluídos, ou não no estudo. 


\subsubsection{Dissecção dos retalhos}

O retalho escapular e o retalho TAP ipsilateral foram dissecados em pares. Com o cadáver em decúbito ventral e com membros superiores em abdução de $90^{\circ}$, foram demarcados os retalhos (figura 5), que foram dissecados seguindo as técnicas descritas a seguir.

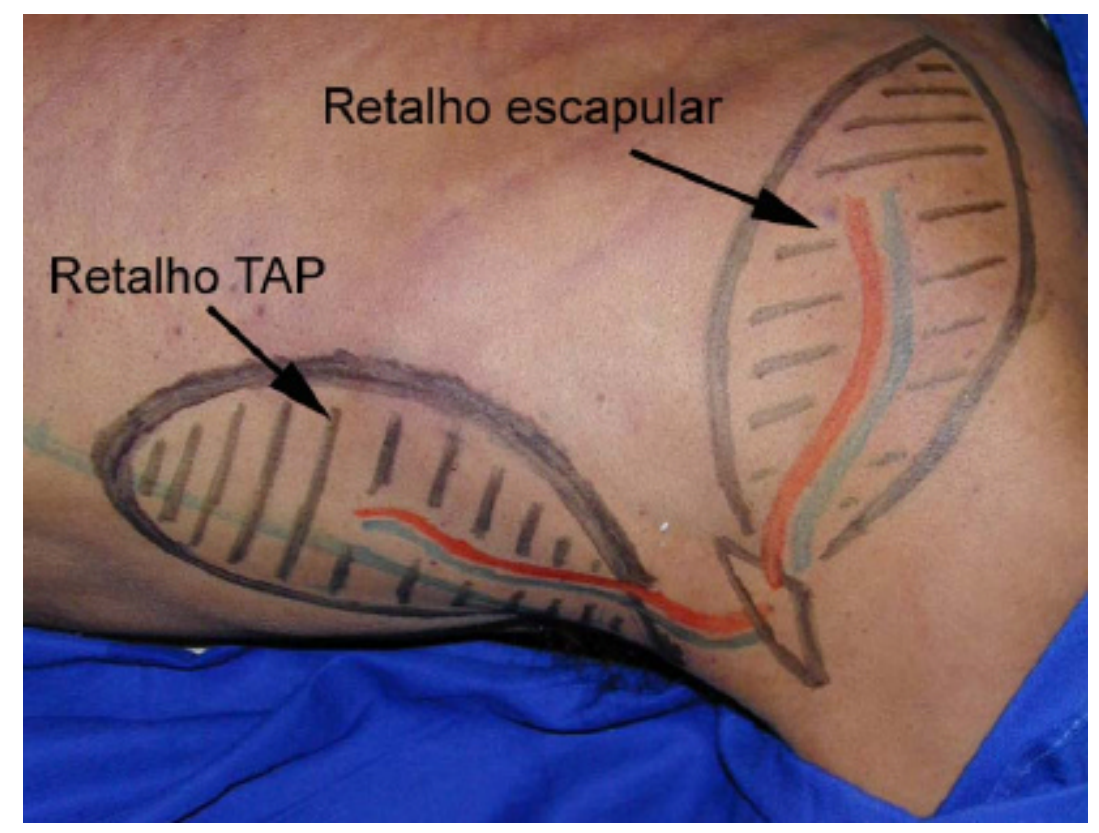

Figura 5. Região dorsal direita de cadáver em decúbito ventral, com o membro superior em abdução de $90^{\circ}$. Demarcação dos retalhos escapular e TAP para dissecção. 


\subsubsection{Retalho Escapular}

Com o cadáver em decúbito ventral, foi realizada demarcação dos parâmetros anatômicos para planejamento do retalho. Através de manobra de palpação, o "espaço triangular" foi demarcado. Os músculos subescapular e redondo menor delimitam sua margem superior; o músculo redondo maior, sua margem inferior; e a cabeça longa do músculo tríceps braquial delimita sua margem lateral (fig. 6).

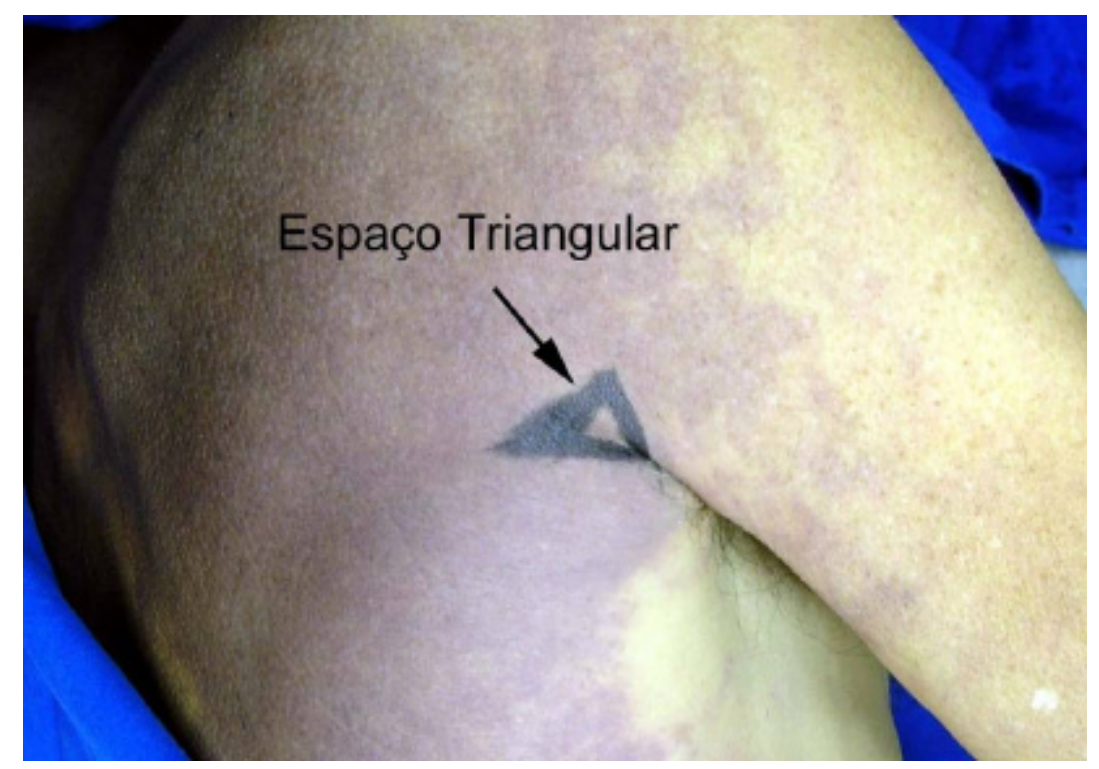

Figura 6. Demarcação do "espaço triangular". Acima se encontram os $\mathrm{mm}$. subescapular e redondo menor; abaixo, o m. redondo maior; e lateralmente, $0 \mathrm{~m}$. tríceps braquial. 
O pedículo circunflexo escapular foi demarcado iniciando no "espaço triangular" em direção à linha média posterior. A ilha cutânea foi centralizada numa linha horizontal, estendendo-se do "espaço triangular" através da superfície posterior da escápula. A extremidade proximal do retalho foi localizada entre a axila e a margem axilar da escápula. A extremidade distal foi demarcada entre a linha média posterior e a margem vertebral da escápula. A largura do retalho foi padronizada em $7 \mathrm{~cm}$, permitindo o fechamento primário da área doadora (fig. 7).

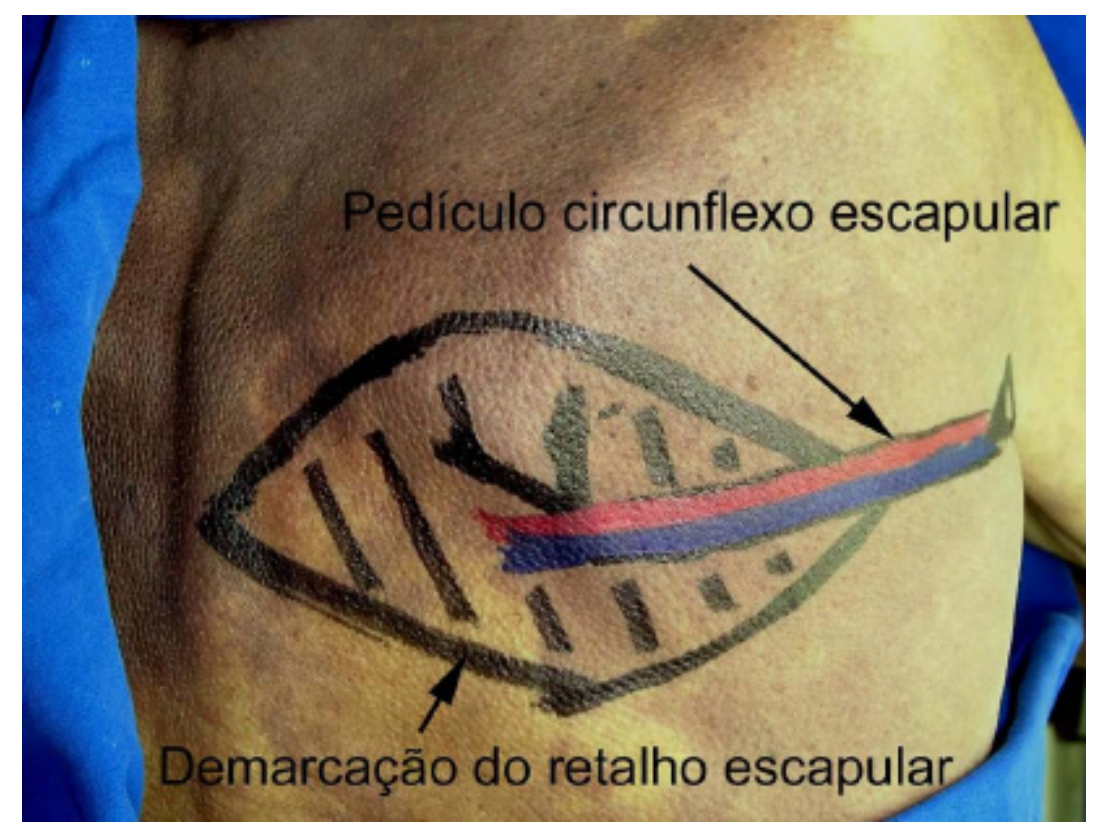

Figura 7. Demarcação da projeção cutânea do pedículo circunflexo escapular a partir do "espaço triangular". O retalho escapular foi demarcado baseado no posicionamento do pedículo. 
Com o retalho demarcado, a dissecção anatômica prosseguiu com a incisão de pele do retalho escapular até o plano abaixo da fáscia profunda (fig. 8). O retalho foi dissecado no plano subfascial a partir da sua porção distal em direção proximal até a identificação da artéria e veia circunflexa escapular.

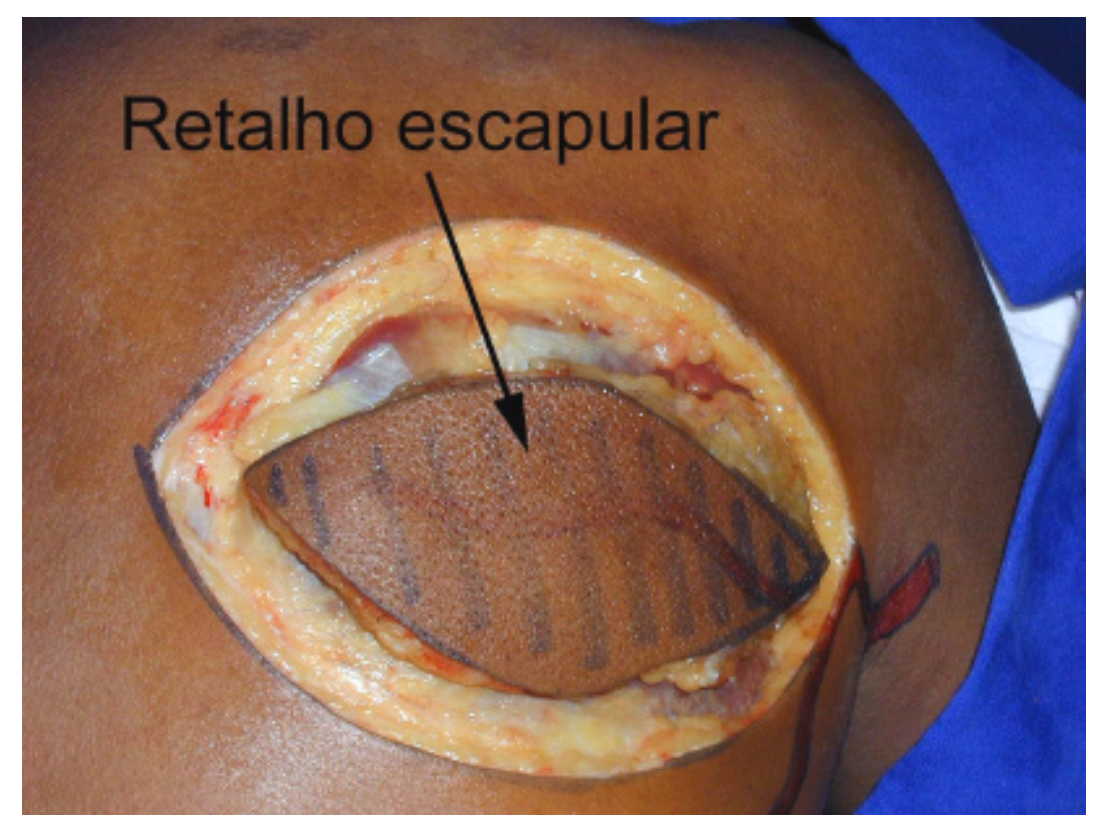

Figura 8. Retalho escapular com sua pele incisada até o plano subfascial. 
A dissecção seguiu com 0 isolamento do pedículo vascular e dissecção do seu trajeto através do "espaço triangular" até sua emergência na artéria e veia subescapulares (fig. 9).

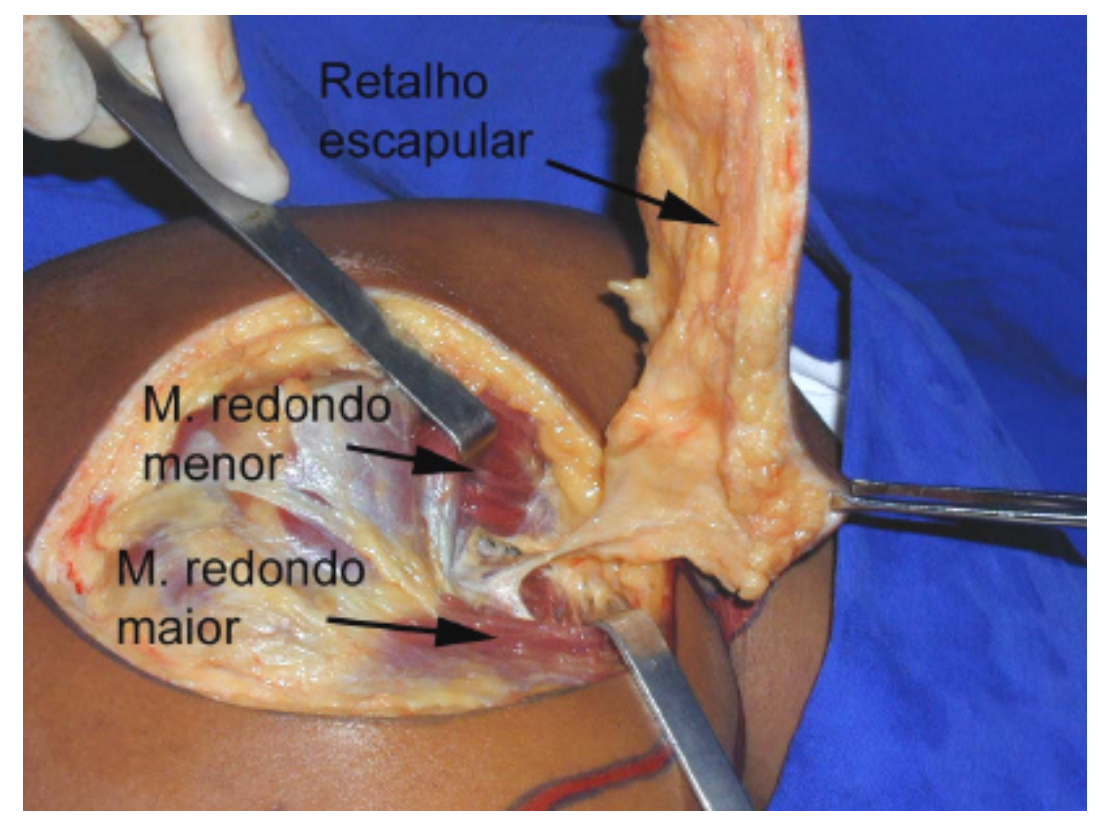

Figura 9. Músculos redondo maior e redondo menor afastados expondo o pedículo circunflexo escapular através do "espaço triangular". 


\subsubsection{Retalho TAP}

Inicialmente a margem lateral do $\mathrm{m}$. latíssimo do dorso foi demarcada através de manobra de palpação. O ramo lateral da artéria toracodorsal foi delimitado, traçando-se uma linha paralela, cerca de $2 \mathrm{~cm}$ medial à margem muscular em direção à fossa axilar.

Foi demarcada uma ilha cutânea de $14 \times 7 \mathrm{~cm}$ correspondente a um retalho perfurante de artéria toracodorsal com seu maior eixo centralizado na projeção cutânea da artéria toracodorsal. Sua largura foi padronizada de forma que permitisse o fechamento primário da área doadora (fig. 10).

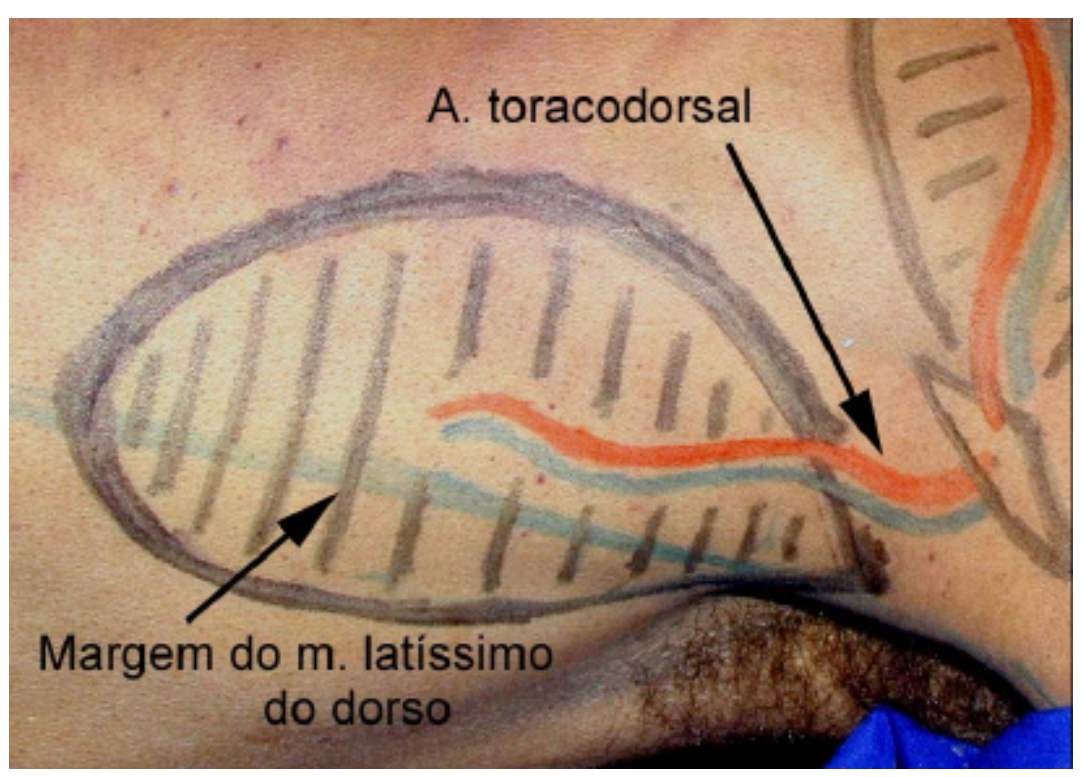

Figura 10. Delimitação da margem lateral do $\mathrm{m}$. latíssimo do dorso. A projeção do pedículo toracodorsal foi demarcada cerca de $2 \mathrm{~cm}$ medialmente a margem muscular, em direção ao cavo axilar. $O$ retalho TAP foi demarcado baseado no posicionamento do pedículo. 
A dissecção do retalho perfurante da artéria toracodorsal se iniciou a partir da incisão da pele até o plano subfascial. O retalho foi dissecado do músculo latíssimo do dorso neste plano até a identificação dos pedículos perfurantes da artéria toracodorsal. O pedículo de maior calibre foi selecionado (fig. 11). Todos os outros pedículos encontrados foram ligados com fio de algodão 4-0.

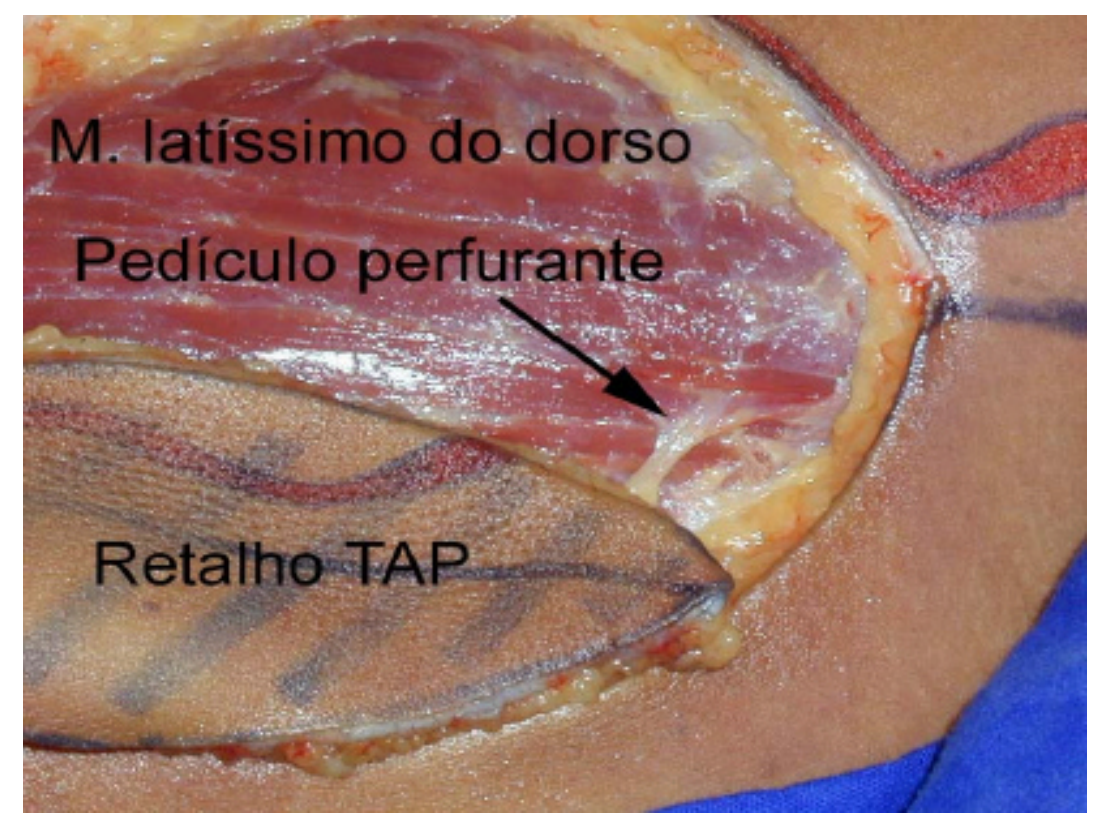

Figura 11. Retalho TAP dissecado do músculo latíssimo do dorso expondo pedículo perfurante através de suas fibras musculares. 
As fibras musculares do músculo grandes dorsal, adjacentes à emergência do pedículo selecionado, foram afastadas no sentido longitudinal, de modo que não houvesse necessidade de secção de fibras musculares. Tal manobra expôs o pedículo perfurante e ramos secundários direcionados para a musculatura (fig. 12).

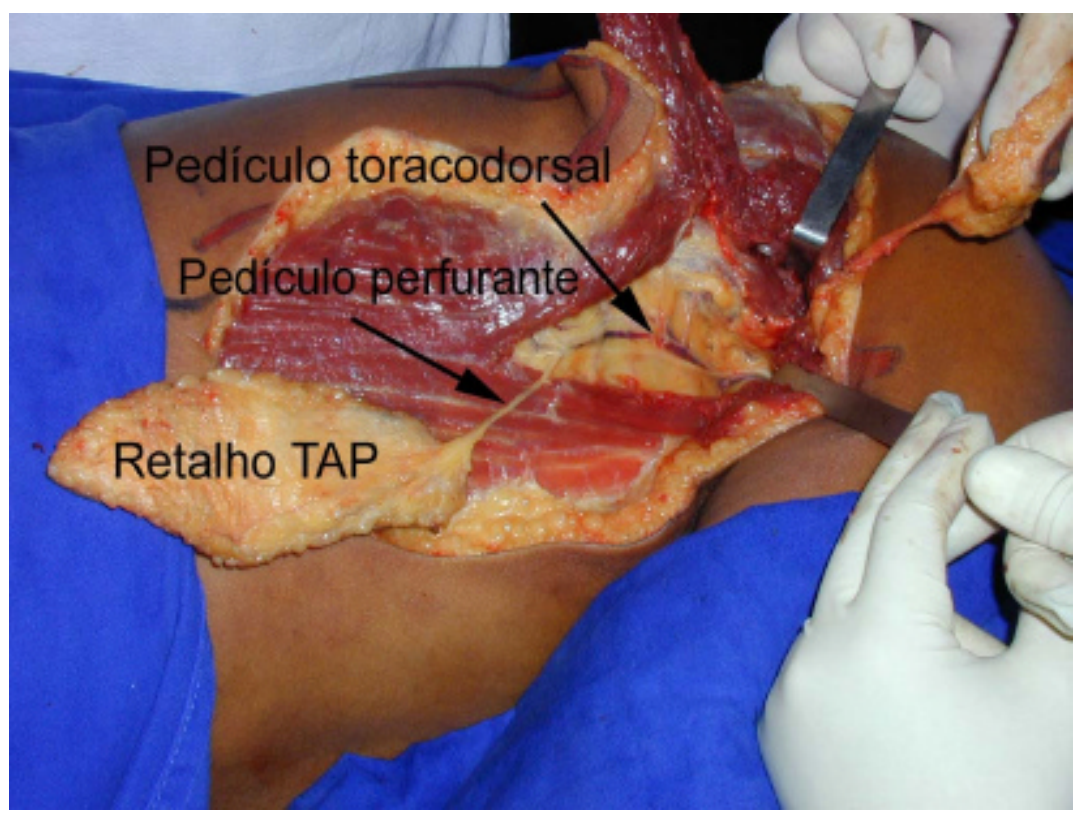

Figura 12. Detalhe da dissecção do retalho TAP. Pedículo perfurante dissecado através da musculatura até o pedículo toracodorsal.

O pedículo foi isolado através de ligaduras dos ramos musculares até a sua emergência no ramo lateral da artéria toracodorsal. O ramo horizontal da artéria toracodorsal foi ligado. A dissecção prosseguiu até o isolamento completo da artéria toracodorsal, desde sua emergência na artéria subescapular. Através de dissecção cuidadosa o nervo toracodorsal foi separado do pedículo vascular. 
O pedículo subescapular foi seccionado imediatamente anterior à bifurcação dos pedículos circunflexos escapulares e toracodorsais. As fibras musculares dos músculos latíssimo do dorso e redondo maior, que se encontrassem entre os dois pedículos, foram seccionadas para permitir a retirada dos retalhos unidos em seus pedículos vasculares (fig. 13).

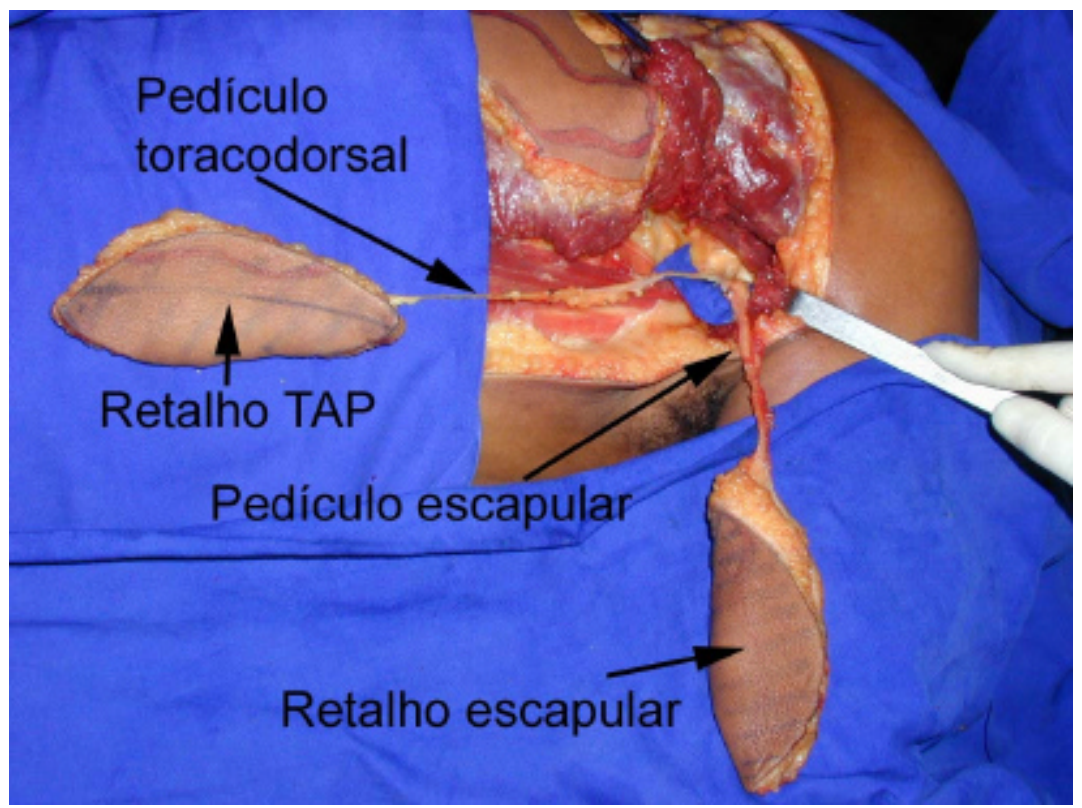

Figura 13. Fibras dos músculos latíssimo do dorso e redondo maior seccionadas expondo os retalhos TAP e escapular dissecados até a junção de seus pedículos na a. subescapular. 


\subsubsection{Coleta de dados}

Com auxílio de um paquímetro digital de margem de erro de 0,0005 mm (fig. 14), foram realizadas as seguintes medições no retalho escapular e no retalho TAP:

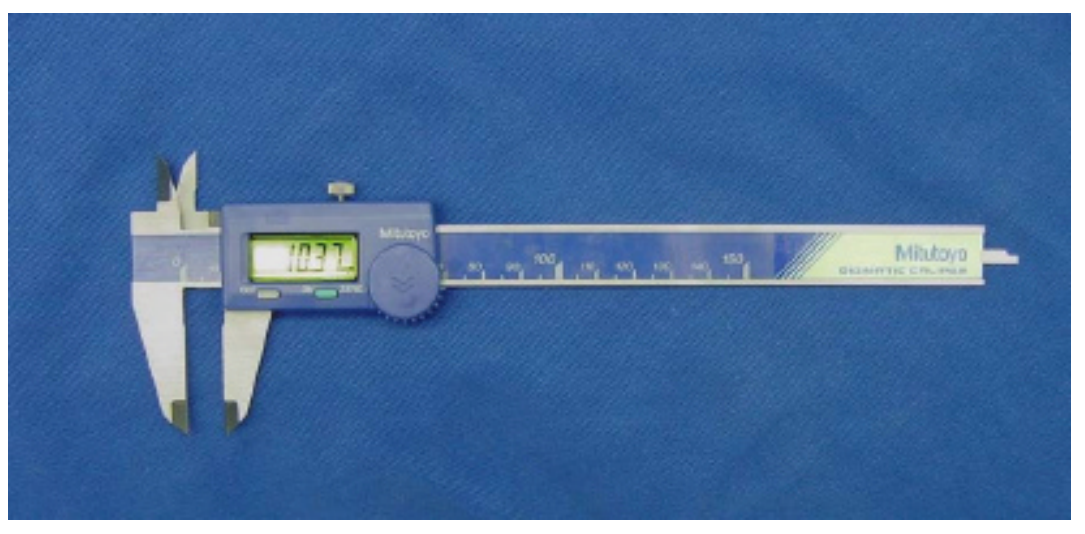

Figura 14. Paquímetro eletrônico da marca Mitutoyo $\AA^{\circledR}$ utilizado na mensuração dos dados coletados. 


\subsubsection{Comprimento dos pedículos}

Os comprimentos dos pedículos circunflexos escapulares e toracodorsais foram medidos desde a bifurcação do pedículo subescapular até o tecido celular subcutâneo do respectivo retalho (fig. 15). O comprimento de cada pedículo circunflexo escapular foi comparado ao comprimento do pedículo toracodorsal correspondente.

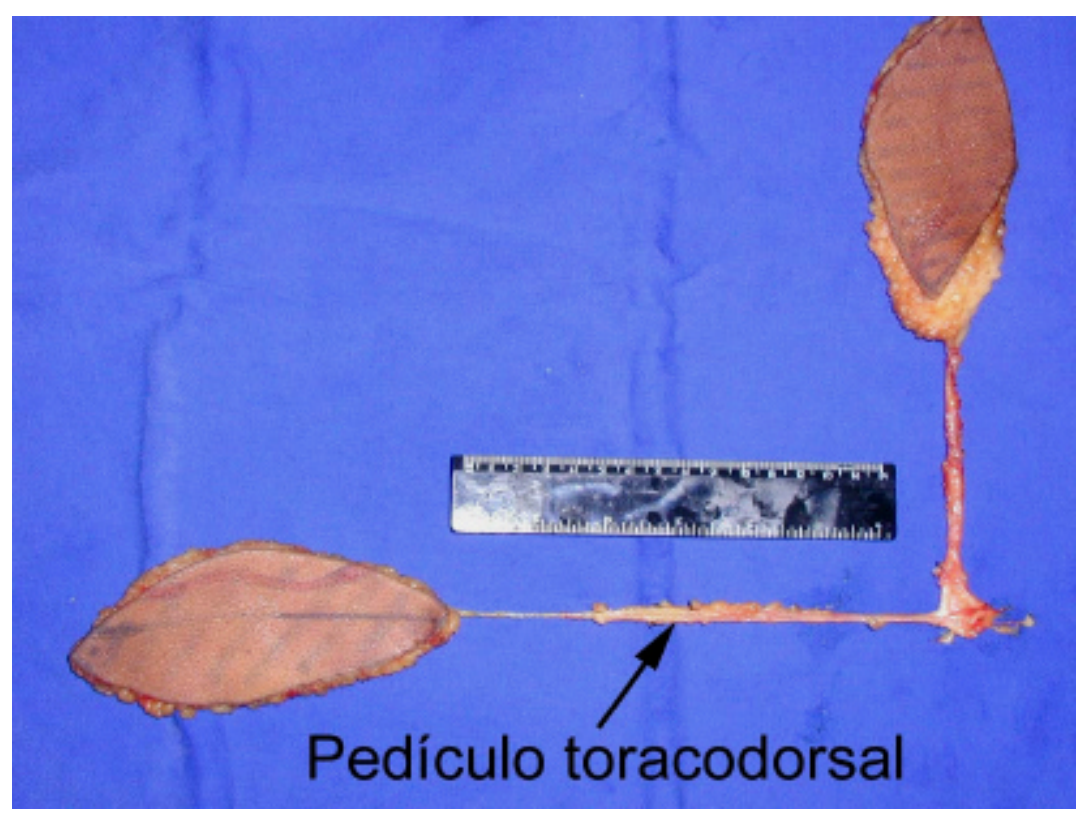

Figura 15. Medição do comprimento total do pedículo do retalho TAP. 


\subsubsection{Diâmetro externo das artérias}

Os diâmetros externos das artérias circunflexas escapulares e toracodorsais foram medidos imediatamente após a bifurcação da artéria subescapular (fig. 16). O diâmetro de cada artéria circunflexa escapular foi comparado ao diâmetro da artéria toracodorsal correspondente.

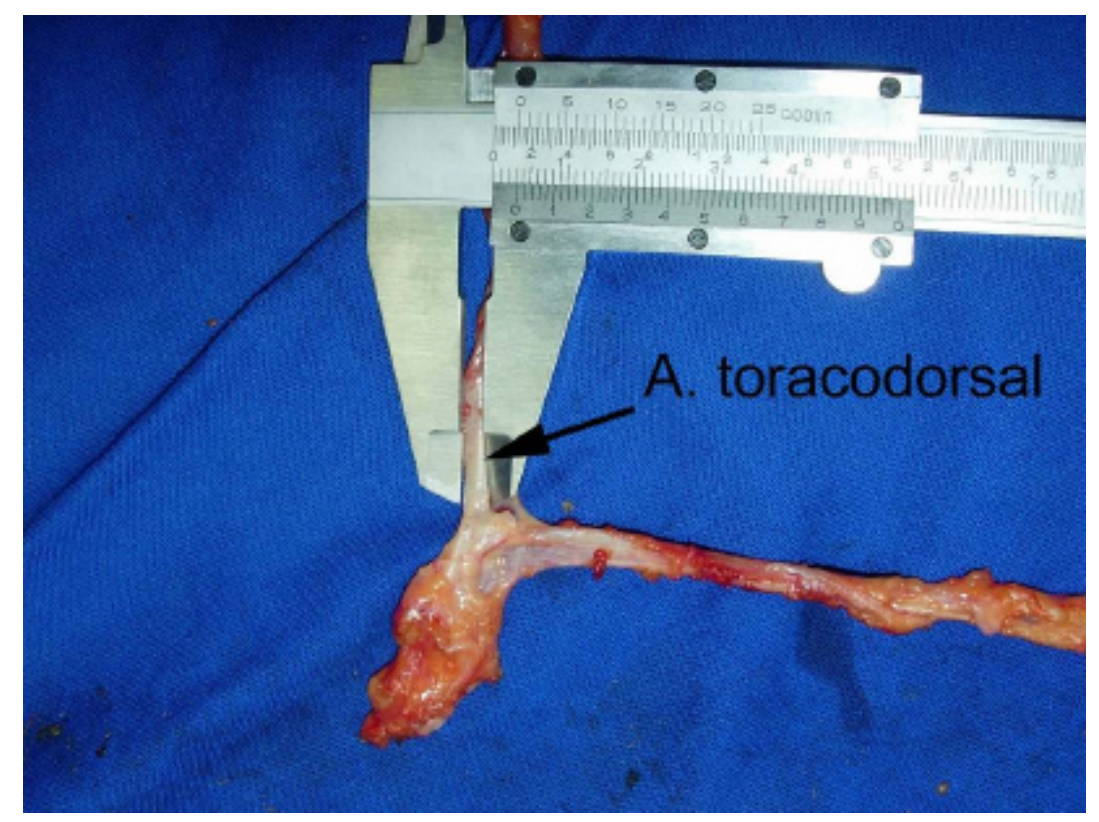

Figura 16. Medição do diâmetro externo da artéria toracodorsal imediatamente após a bifurcação da a. subescapular. 


\subsubsection{Diâmetro externo das veias}

Os diâmetros externos das veias circunflexas escapulares e toracodorsais foram medidos imediatamente antes da junção das mesmas na veia subescapular (fig.17). O diâmetro de cada veia circunflexa escapular foi comparado ao diâmetro da veia toracodorsal correspondente.

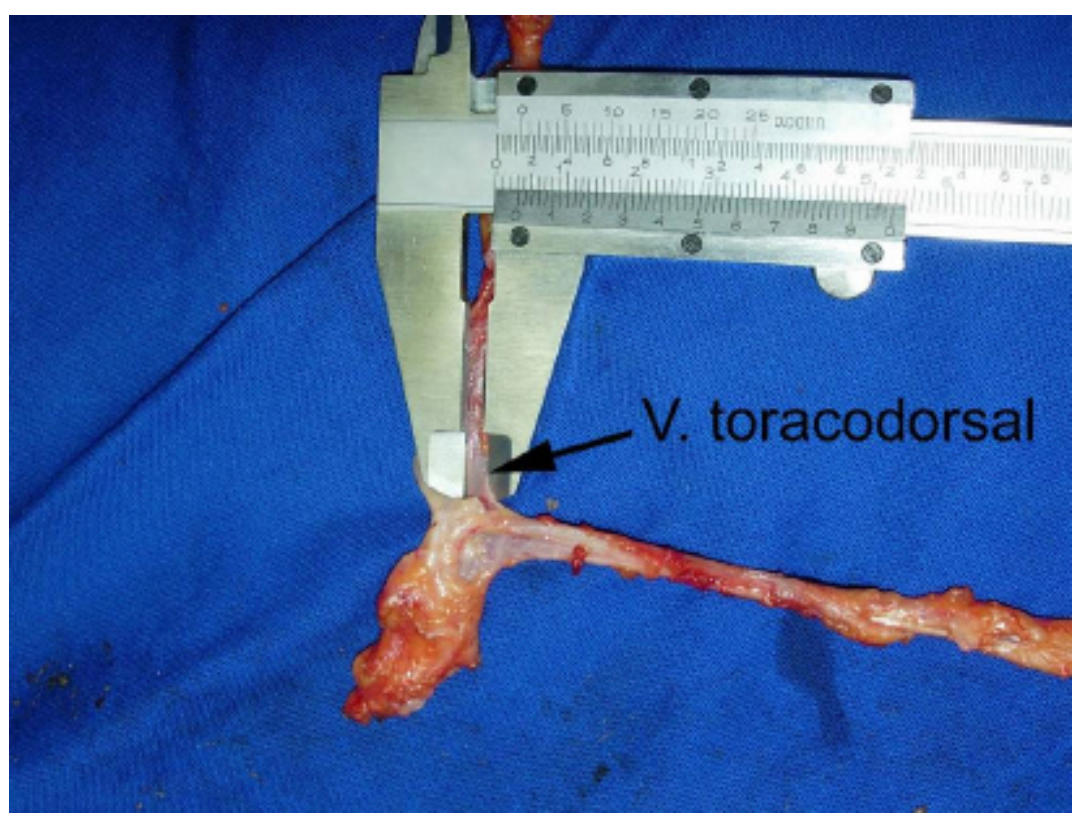

Figura 17. Medição do diâmetro externo da veia toracodorsal imediatamente antes da confluência na v. subescapular. 


\subsubsection{Espessura da derme}

A espessura da derme dos retalhos escapulares e dos retalhos TAP foi medida no ponto médio do retalho em relação ao seu comprimento. Nos retalhos escapulares, a medida foi realizada na margem caudal (fig. 18); e nos retalho TAP, a medida foi realizada na margem medial. A espessura da derme de cada retalho escapular foi comparada à espessura da derme do retalho TAP correspondente.

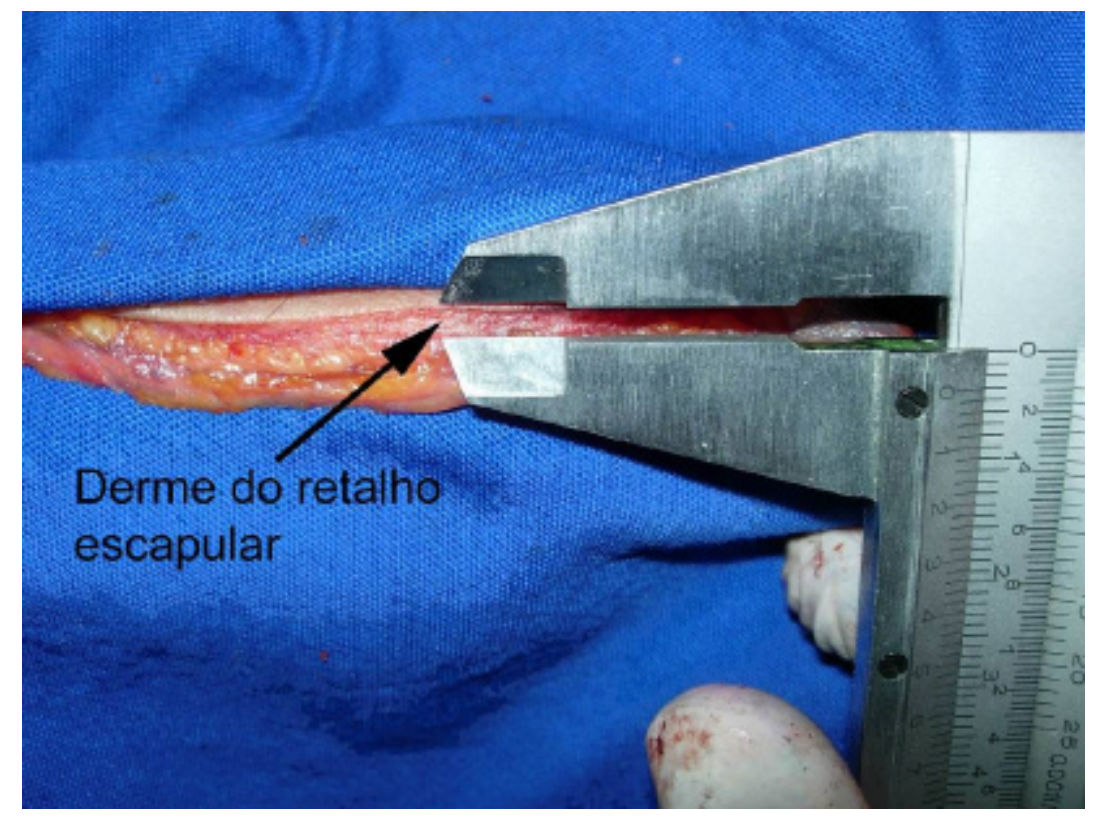

Figura 18. Medição da derme do retalho escapular na margem caudal do mesmo e no ponto médio em relação ao comprimento. 


\subsubsection{Espessura do tecido celular subcutâneo}

A espessura do tecido celular subcutâneo dos retalhos escapulares e dos retalhos TAP foi medida no ponto médio do retalho em relação ao seu comprimento. Nos retalhos escapulares, a medida foi realizada na margem caudal (fig. 19). Nos retalhos TAP, a medida foi realizada na margem medial. A espessura do tecido celular subcutâneo de cada retalho escapular foi comparada à espessura do tecido celular subcutâneo do retalho TAP correspondente.

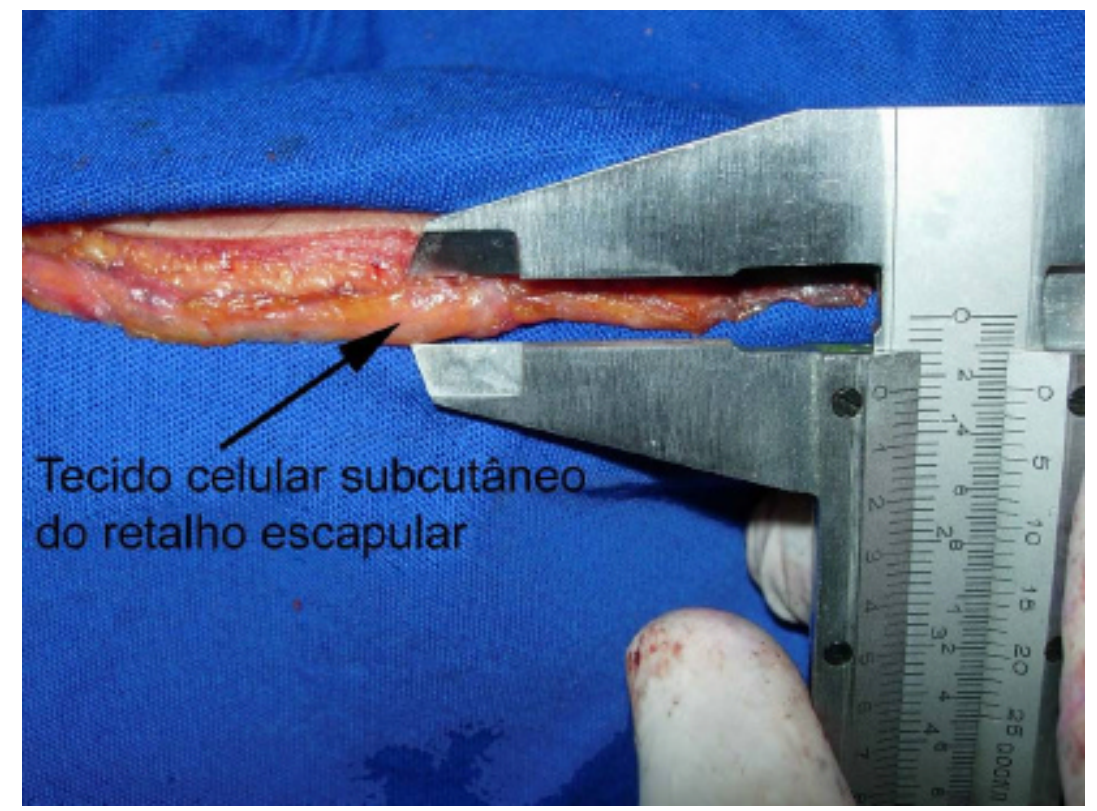

Figura 19. Medição do tecido celular subcutâneo do retalho escapular na margem caudal do mesmo e no ponto médio em relação ao comprimento. 


\subsubsection{Localização dos pedículos}

Nas dissecções dos retalhos escapulares, a localização dos pedículos circunflexos escapulares foi avaliada em relação ao "espaço triangular".

Nas dissecções dos retalhos TAP, a localização dos pedículos perfurantes encontrados foi avaliada em relação à distância da margem anterior do $\mathrm{m}$. latíssimo do dorso e em relação à distância do início do cavo axilar (fig. 20). Para melhor visualização da distribuição dos pedículos perfurantes foram utilizados gráficos de freqüências absolutas independentes referentes à distância do $\mathrm{m}$. latíssimo do dorso e do início do cavo axilar.

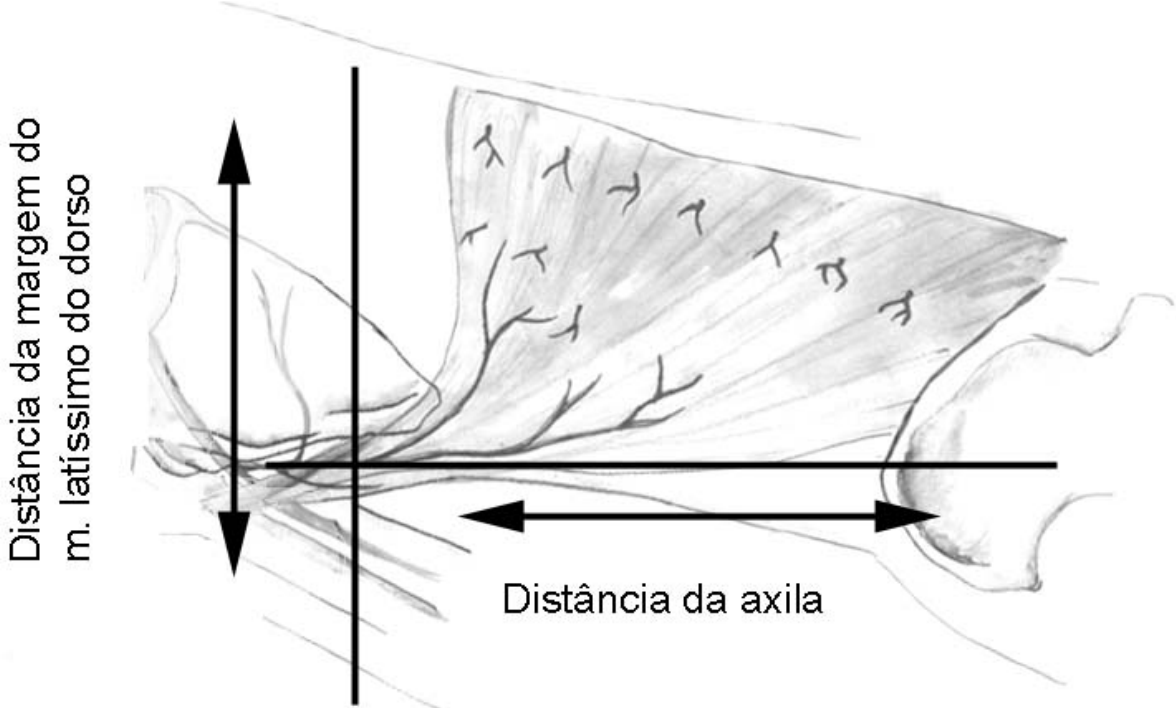

Figura 20. Esquema representativo do dorso humano com a delimitação dos eixos para avaliação da localização dos pedículos perfurantes da a. toracodorsal. 0 eixo horizontal representa a distância do cavo axilar, enquanto o eixo vertical representa a distância da margem lateral do $\mathrm{m}$. latíssimo do dorso. 


\subsubsection{Análise dos dados}

As análises comparativas do comprimento dos pedículos, diâmetro externo das artérias, diâmetro externo das veias, espessura da derme e espessura do tecido subcutâneo foram realizadas de forma pareada, isto é, cada retalho escapular foi comparado exclusivamente ao retalho TAP correspondente.

Com auxílio do programa Excel®, foi utilizado o teste estatístico t de Student pareado. Os valores de $p<0,05$ foram considerados estatisticamente significantes. 
4. Resultados 
4.1 Comprimento dos pedículos

O comprimento do pedículo do retalho escapular variou de 7 a $15 \mathrm{~cm}$, com média de $11,29 \pm 1,62 \mathrm{~cm}$, enquanto o retalho TAP variou de 13,5 a 22 cm, com média de 16,95 $\pm 2,01 \mathrm{~cm}$ (fig. 21). Em todos os cadáveres dissecados, os pedículos dos retalhos TAP foram mais longos do que os dos retalhos escapulares correspondentes. A análise comparativa pareada entre os dois retalhos demonstrou que o pedículo do retalho TAP é $50,5 \%$ mais longo do que o pedículo do retalho escapular ( $p<0,0001)$ (fig. 22).

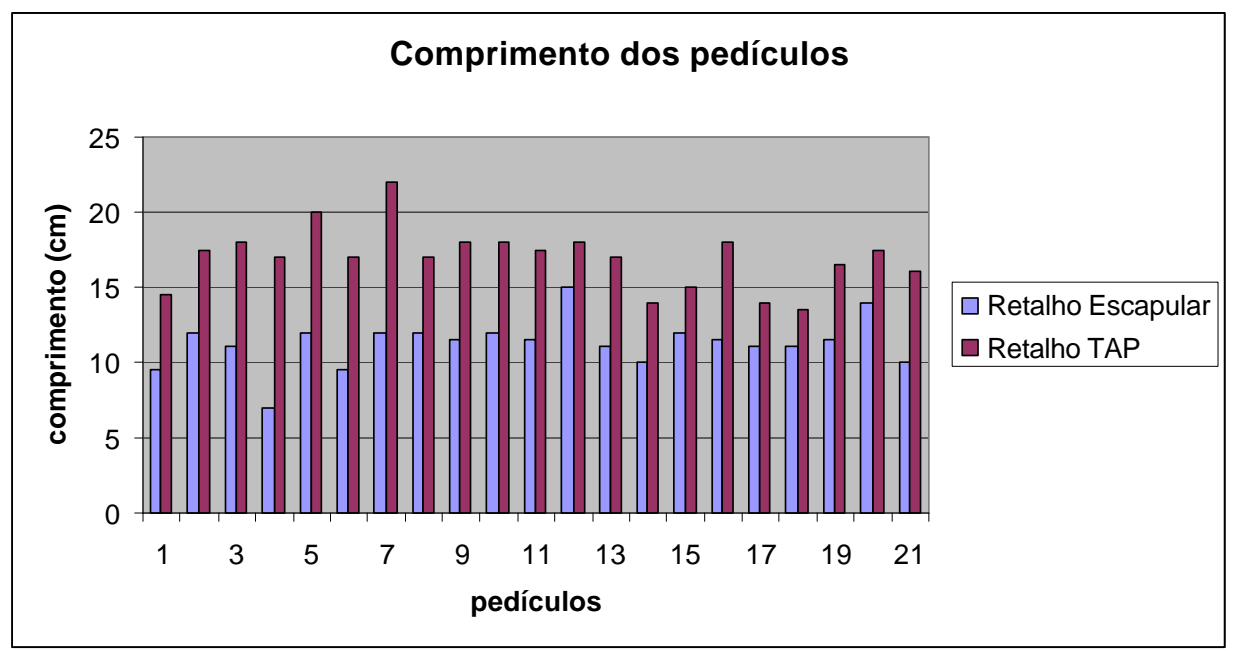

Figura 21. Gráfico de barras demonstrando o comprimento dos pedículos toracodorsais e circunflexos escapulares em cada dissecção. 


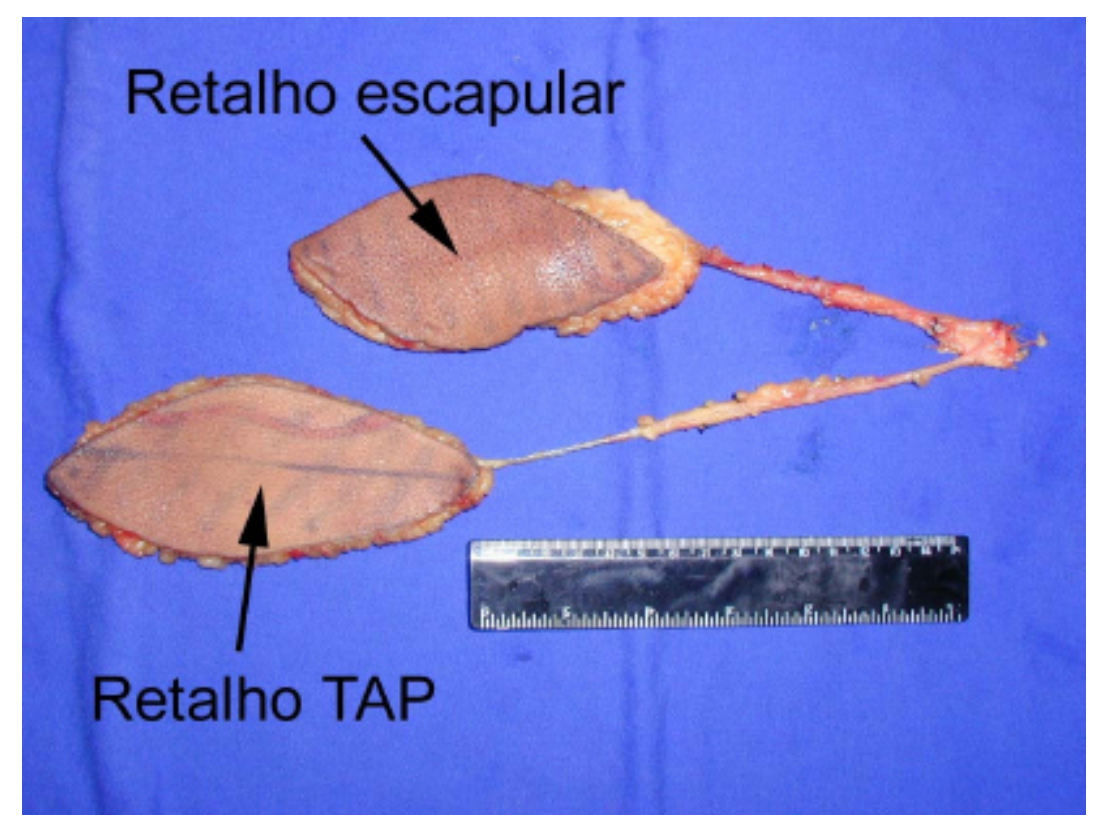

Figura 22. Retalhos TAP e escapular, unidos pela junção de seus pedículos na a. subescapular, demonstrando a diferença de comprimento entre os dois pedículos. 


\subsection{Diâmetro externo das artérias}

O diâmetro externo da artéria circunflexa escapular variou de 1 a 5 $\mathrm{mm}$, com média de $3,33 \pm 1,00 \mathrm{~mm}$, enquanto a a. toracodorsal variou de 1,5 a 4,5 mm, com média de 3,14 $\pm 0,69 \mathrm{~mm}$ (fig. 23). A análise comparativa pareada entre as duas artérias não demonstrou diferença estatisticamente significante $(p>0,1)$.

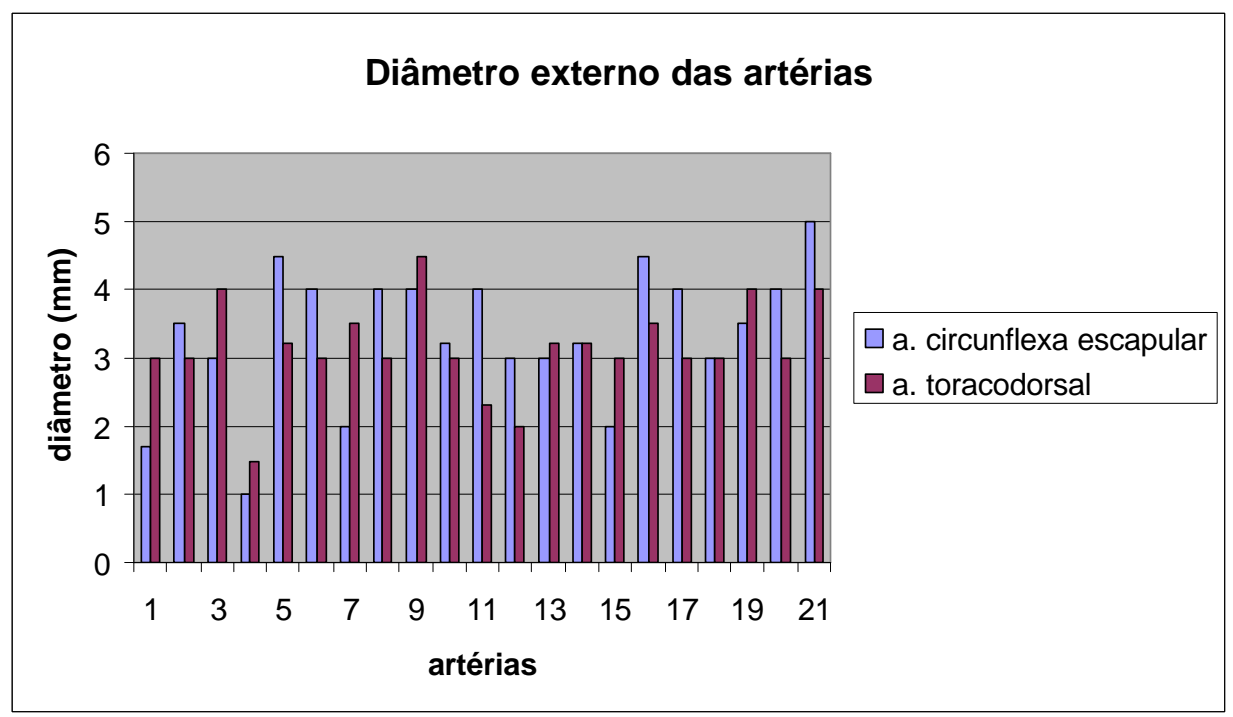

Figura 23. Gráfico de barras demonstrando o diâmetro externo das artérias toracodorsais e circunflexas escapulares em cada dissecção. 


\subsection{Diâmetro externo das veias}

O diâmetro externo da veia circunflexa escapular variou de 1,3 a 5 $\mathrm{mm}$, com média de $3,35 \pm 1,03 \mathrm{~mm}$, enquanto a v. toracodorsal variou de 2 a $5 \mathrm{~mm}$, com média de $3,30 \pm 0,82 \mathrm{~mm}$ (fig. 24). A análise comparativa pareada entre as duas veias não demonstrou diferença estatisticamente significante $(p>0,5)$.

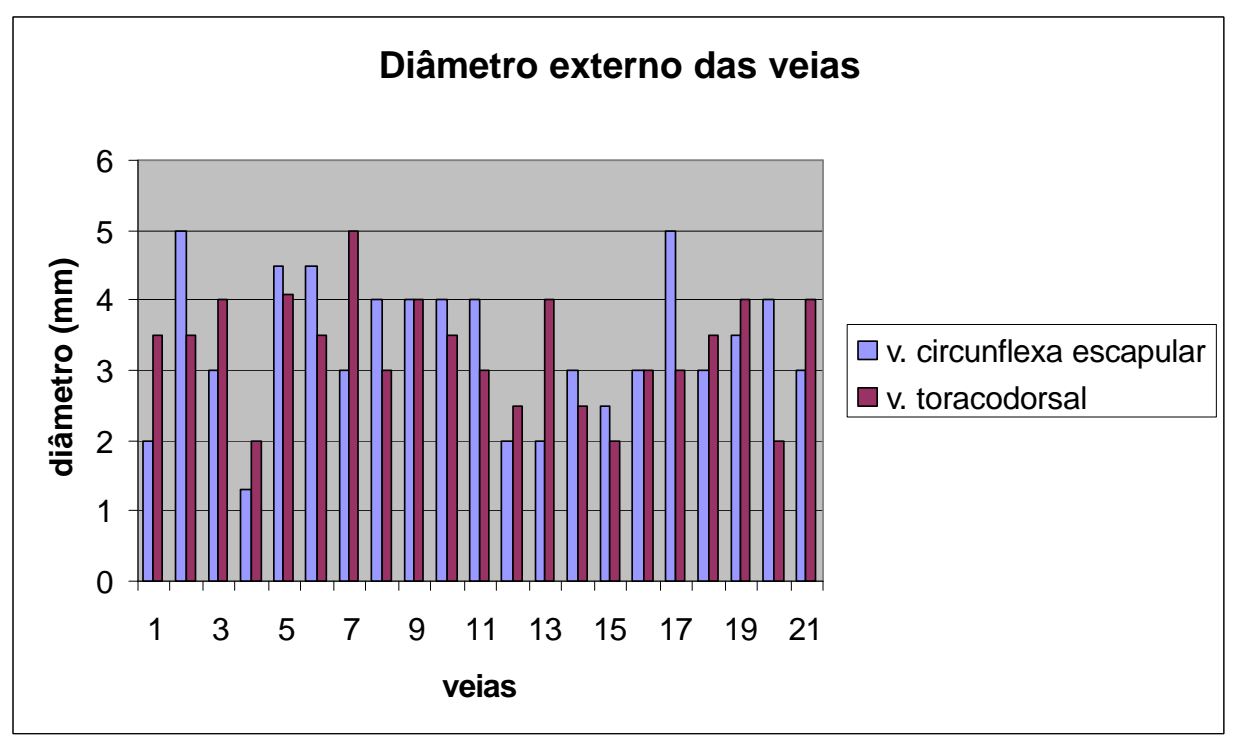

Figura 24. Gráfico de barras demonstrando o diâmetro externo das veias toracodorsais e circunflexas escapulares em cada dissecção. 


\subsection{Espessura da derme}

A espessura da derme do retalho escapular variou de 1,5 a $4,6 \mathrm{~mm}$, com média de $3,02 \pm 1,12 \mathrm{~mm}$, enquanto a derme do retalho TAP variou de 1,3 a 3,0 mm, com média de 2,12 $\pm 0,65 \mathrm{~mm}$ (fig. 25). A análise comparativa pareada demonstrou que a derme do retalho escapular é $41 \%$ mais espessa do que a do retalho TAP $(p<0,05)$

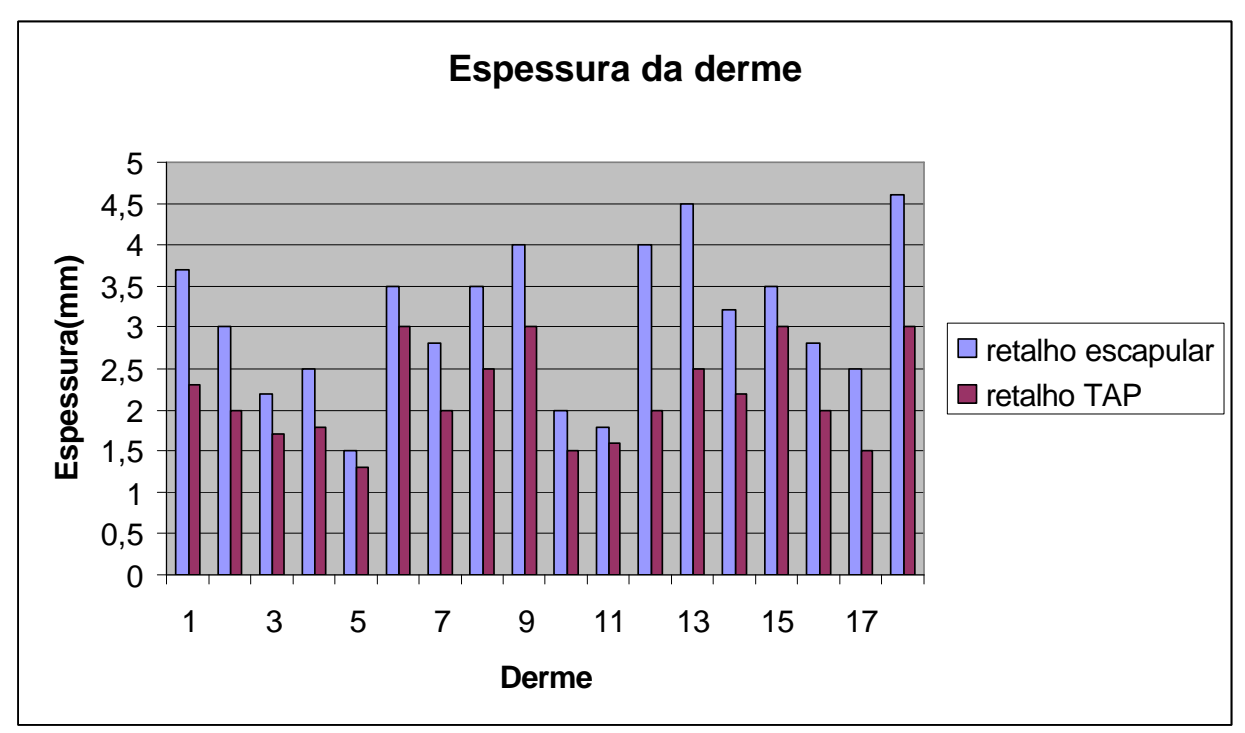

Figura 25. Gráfico de barras demonstrando a diferença de espessura da derme dos retalhos TAP e escapular em cada dissecção. 
4.5 Espessura do tecido celular subcutâneo

A espessura do tecido celular subcutâneo do retalho escapular variou de 1,0 a $3,0 \mathrm{~cm}$, com média de $1,76 \pm 0,50 \mathrm{~cm}$, enquanto a do retalho TAP variou de 0,6 a $3,0 \mathrm{~cm}$, com média de $1,37 \pm 0,55 \mathrm{~cm}$ (fig. 26). A análise comparativa pareada demonstrou que o tecido celular subcutâneo do retalho escapular é $28 \%$ mais espesso do que o tecido celular subcutâneo do retalho TAP ( $p<0,0001)$ (fig. 27).

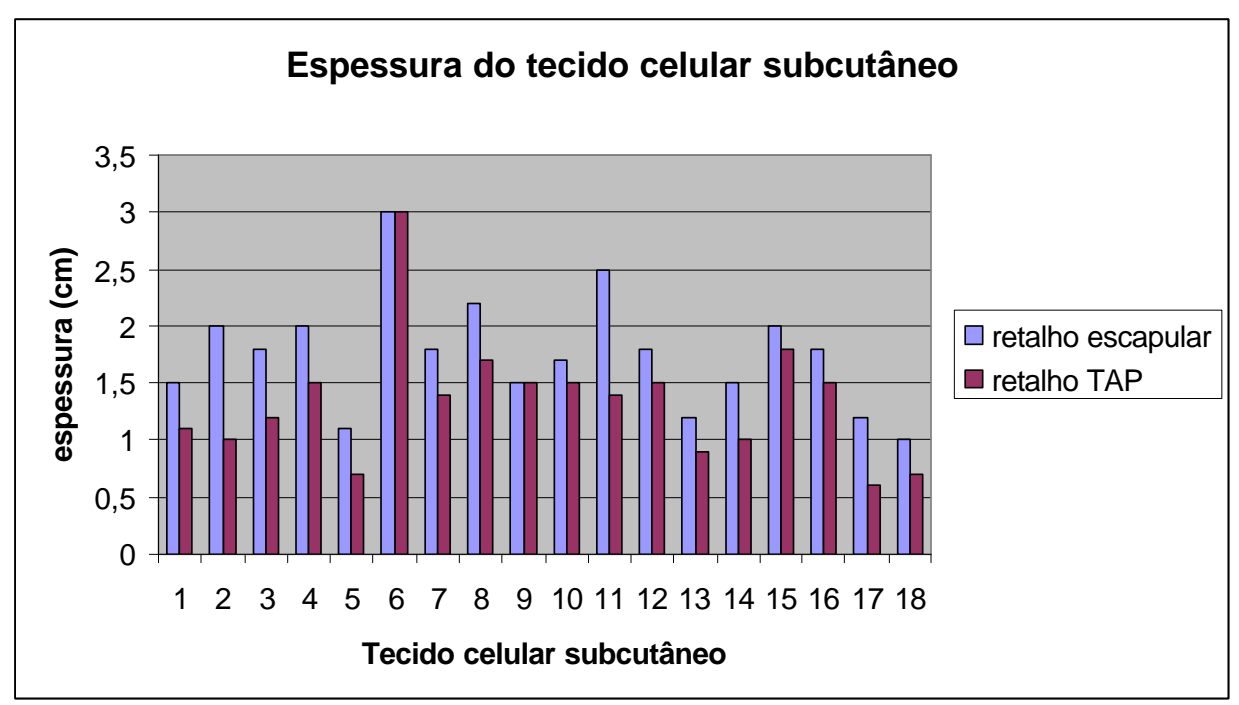

Figura 26. Gráfico de barras demonstrando a diferença de espessura tecido celular subcutâneo dos retalhos TAP e escapular em cada dissecção. 


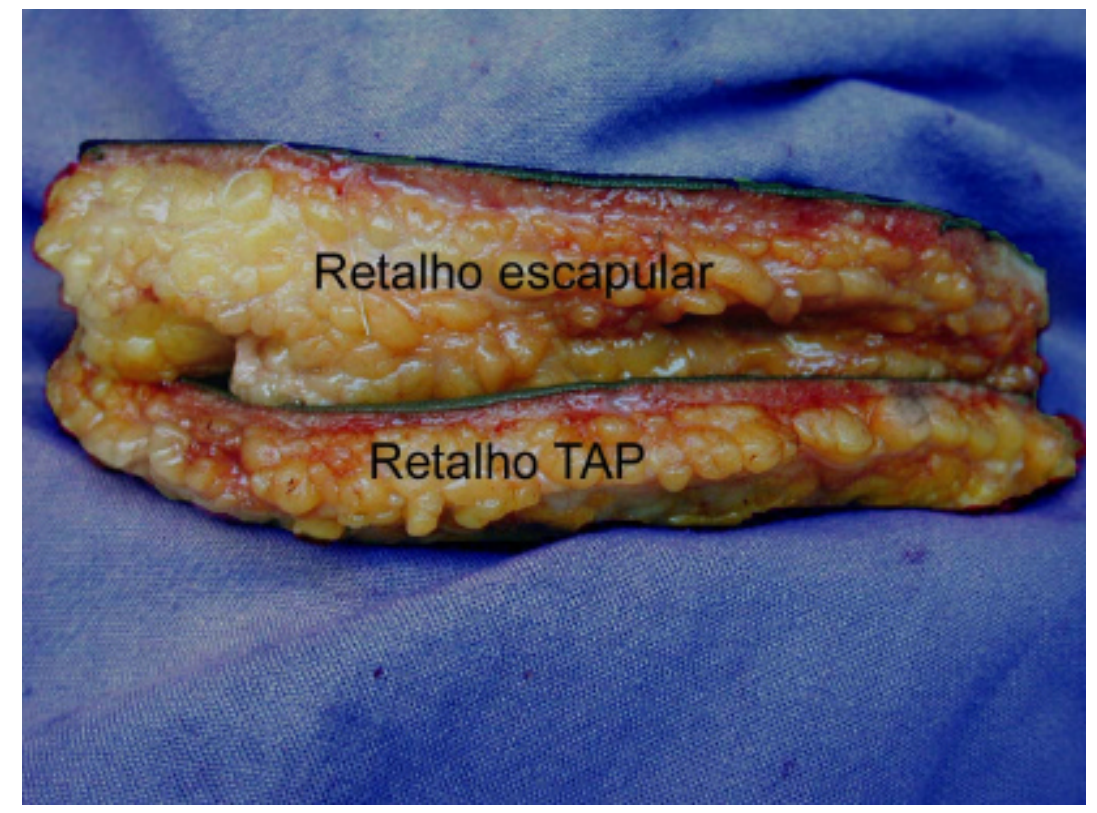

Figura 27. Retalho escapular sobreposto ao retalho TAP demonstrando a diferença de espessura da derme e do tecido celular subcutâneo. 
4.6 Localização dos pedículos

Em todas as dissecções do retalho escapular, os pedículos circunflexos escapulares foram encontrados no "espaço triangular", compreendido entre os músculos subescapular e redondo menor superiormente, redondo maior inferiormente e cabeça longa do tríceps lateralmente.

A localização dos pedículos perfurantes do pedículo toracodorsal em relação ao músculo latíssimo do dorso foi muito variável, conforme se pode observar na figura 28. Na avaliação da freqüência absoluta da localização das perfurantes em relação à distância do cavo axilar, não se observou padronização na distribuição (fig. 29). Porém, na análise da localização das perfurantes em relação à distância da margem do m. latíssimo do dorso, observou-se uma predominância na localização de pedículos a cerca de 2 cm da margem ( $71,4 \%$ dos pedículos) (fig. 30).

Foram encontrados dois pedículos anteriores à margem do $\mathrm{m}$. latíssimo do dorso, com trajeto paralelo à margem muscular. Tais pedículos eram ramos diretos da a. toracodorsal. 


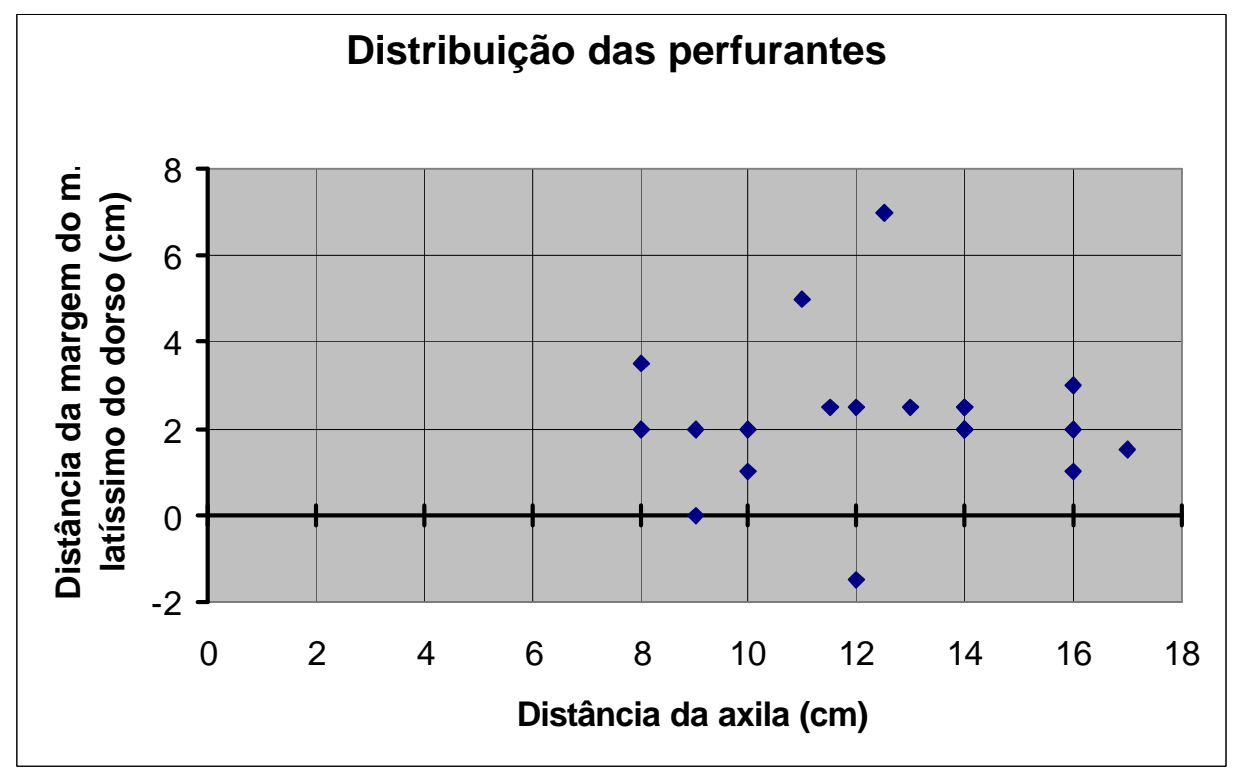

Figura 28. Gráfico demonstrando a distribuição da emergência dos pedículos perfurantes em relação a distância da margem do músculo latíssimo do dorso e do cavo axilar.

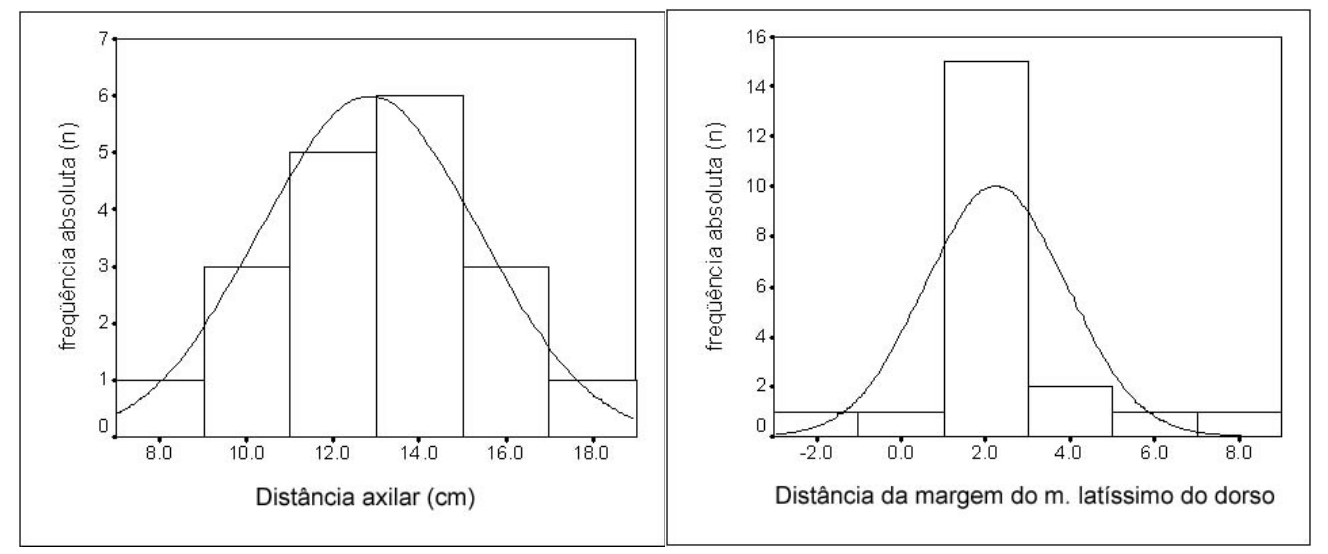

Figura 29 e 30. Gráficos demonstrando a freqüência absoluta do posicionamento da emergência dos pedículos perfurantes relacionados independentemente a margem do m. latíssimo do dorso e da distância do cavo axilar. 
5. Discussão 
O processo de escolha de um ou de outro retalho é uma etapa fundamental no planejamento das cirurgias reconstrutivas. Cada retalho possui características distintas que refletem suas características anatômicas pré-determinadas, incluindo localização, tamanho, tipo de tecidos, espessura, textura, padrões de circulação, fluxo sanguíneo, inervação e função.

Os critérios adotados para a escolha de um retalho variam de acordo com as preferências do cirurgião, entretanto, algumas características tornam um retalho mais ou menos favorável à reconstrução de determinado defeito. A compatibilidade do defeito e do retalho a ser utilizado é, de modo geral, o objetivo final na escolha de um retalho.

Dentre as regiões doadoras de retalhos do corpo humano, a região póstero-lateral do tronco tem sido utilizada preferencialmente por diversos autores. Trata-se de uma região coberta por vestimentas habituais; geralmente possui pouca pilificação e possui um plexo vascular constante e bem conhecido (Kim et al, 2001; Guerra et al, 2004; Hamdi et al, 2004).

Com o recente desenvolvimento dos retalhos perfurantes, o retalho TAP foi descrito como nova opção de retalho cutâneo na região dorsal (Angrigiani et al, 1995). Porém, o retalho escapular, de características semelhantes, já se encontra bem estabelecido como retalho confiável e versátil (Thoma et al, 1990; Maruyama, 1991; Bonato et al, 2002; Germann, 2004). Até o momento, nenhum estudo demonstrou dados concretos que diferenciem os retalhos TAP e escapular. Este estudo se propôs a diferenciar anatomicamente os dois retalhos. 
Munhoz (2004), em sua dissertação de mestrado, utilizou a sigla DIEP, derivada do termo em inglês "deep inferior epigastric perforator" para especificar o pedículo perfurante da artéria epigástrica profunda inferior. Tal decisão resultou da falta de correspondência do termo em língua inglesa com o termo em língua portuguesa, pois o termo perfurante, conforme o dicionário da língua portuguesa Houaiss (2003), é um adjetivo e como tal atribui ao substantivo artéria, a qualidade ou estado de "perfurar furando".

Até o momento, não encontramos publicações em língua portuguesa que citem o retalho TAP. Este fato confere à presente dissertação a originalidade na denominação do retalho na língua portuguesa. Assim como Munhoz (2004), optamos por utilizar a sigla da língua inglesa TAP, derivado do termo "thoracodorsal artery perforator", pois a tradução "perfurante da artéria toracodorsal" não possui significado compatível na língua portuguesa, pois o retalho não apresenta a qualidade de "perfurar furando".

Para a realização deste estudo foram utilizadas dissecções anatômicas em cadáveres. Desse modo, foi possível dissecar os dois retalhos simultaneamente no mesmo cadáver, possibilitando uma análise pareada dos dados obtidos. Isto é, cada retalho TAP foi comparado exclusivamente com o retalho escapular ipsilateral no mesmo indivíduo, o que tornou a comparação mais fiel. 
Dados relativos ao comprimento médio do pedículo do retalho escapular são discordantes na literatura. Dos Santos (1984), em seu trabalho original, obteve um comprimento médio deste pedículo de $4 \mathrm{~cm}$. Hamilton et al (1982) encontraram média de $6 \mathrm{~cm}$ de comprimento. Nassif et al (1982) obtiveram média de 7 a $10 \mathrm{~cm}$ de comprimento. No presente estudo, o comprimento médio do pedículo foi de $11,29 \mathrm{~cm}$. Tal variação deve estar relacionada à extensão total da dissecção do pedículo.

O comprimento médio do pedículo do retalho TAP encontrado neste estudo foi de $16,95 \mathrm{~cm}$, menor do que os resultados obtidos por Guerra et al (2004), que encontraram pedículos com média de comprimento de $20 \mathrm{~cm}$. A diferença de comprimento encontrada deve-se, provavelmente, às diferentes técnicas de dissecção empregadas. Tais autores dissecaram o pedículo até a artéria axilar incluindo a a. subescapular no comprimento total. Clinicamente, tal dissecção é raramente necessária, e tecnicamente difícil, devido à profundidade do campo cirúrgico, portanto optamos por dissecar o pedículo até a emergência do pedículo circunflexo escapular.

Hamdi et al (2004), afirmaram que o pedículo do retalho TAP seria cerca de 4 a $5 \mathrm{~cm}$ mais longo do que o retalho paraescapular. O presente estudo apresentou resultados compatíveis com tal afirmação, pois o comprimento do pedículo do retalho TAP foi, em média, 5,66 cm mais longo do que o do retalho escapular. Isto significa que o comprimento do pedículo do retalho TAP foi $50,5 \%$ maior do que o comprimento do pedículo do retalho escapular. Tal característica representa uma vantagem do retalho TAP em relação ao retalho escapular. Pedículos maiores representam uma 
segurança maior para transferências microcirúrgicas. Além disso, há maior facilidade técnica na anastomose vascular. Em alguns casos, o maior comprimento do pedículo pode evitar a necessidade de enxertos vasculares. Em retalhos em ilha, este aumento de comprimento representa um maior arco de rotação para o retalho, ampliando as possibilidades de indicação dos retalhos locais (Mathes; Nahai, 1997).

Shimizu et al (1997), realizaram um estudo anatômico em 42 cadáveres de etnia japonesa, no qual avaliaram o diâmetro da artéria e veia circunflexas escapulares. Os autores encontraram artérias com diâmetro médio de 2,8 mm, e veias com diâmetro médio de $3,3 \mathrm{~mm}$. Os resultados obtidos neste estudo foram semelhantes, sendo o diâmetro arterial médio de $3,33 \mathrm{~mm}$ e o venoso de $3,35 \mathrm{~mm}$.

O presente estudo não demonstrou diferença estatística em relação ao diâmetro externo tanto das artérias como das veias de ambos os retalhos, o que confere dificuldade técnica similar de se realizar uma anastomose vascular microcirúrgica. Deve-se salientar que os diâmetros de tais vasos são considerados grandes, em média maiores do que $3 \mathrm{~mm}$, o que facilita tecnicamente tais anastomoses (Mathes; Nahai, 1997).

Na cirurgia reconstrutiva, em determinadas situações, a utilização de um retalho com pele delgada é preferível, quando comparado aos retalhos de pele espessa. Reconstruções de pele de regiões em que a espessura original é fina obviamente irão se beneficiar de retalhos finos. Tal situação se aplica às reconstruções de mão, membros inferiores, superfícies articulares e pescoço. Retalhos finos são igualmente desejáveis nas reconstruções 
tridimensionais em que há necessidade de modelagem do retalho. Tais situações são comuns em reconstruções complexas de cabeça e pescoço e de extremidades (Mathes; Nahai, 1997).

O emagrecimento do retalho num segundo tempo sempre é possível. Pode ser realizado sob visão direta, ou através de lipoaspiração. Entretanto, tal procedimento diminui exclusivamente a espessura do tecido celular subcutâneo, pois o adelgaçamento da derme não é aconselhável, por comprometer a circulação cutânea. Além disso, tal procedimento representa um tempo cirúrgico adicional (Koshima et al, 1999; Kim et al, 2001).

Germann (2004) afirmou que os retalhos escapulares e paraescapulares possuem a mesma espessura de pele do retalho TAP. No presente estudo, os resultados obtidos contrariam a afirmação supracitada. O retalho TAP apresentou derme $41 \%$ mais delgada e o tecido celular subcutâneo $28 \%$ mais delgado do que o retalho escapular. Logo, em relação à espessura da pele, o retalho TAP é preferível ao retalho escapular em situações em que haja necessidade de um retalho fino.

A localização do pedículo do retalho escapular no "espaço triangular" foi constante em todas as dissecções deste estudo. Tal resultado é compatível com outros estudos anatômicos sobre os retalhos escapulares, e confirmam a vantagem deste retalho de possuir anatomia constante e confiável (Dos Santos, 1980; Gilbert; Teot, 1982; Barwick et al, 1982). 
Dados relativos à localização do pedículo perfurante do retalho TAP têm sido discordantes em publicações prévias. Angrigiani et al (1995) realizaram estudo anatômico com dissecção de 40 cadáveres frescos, no qual descreveram a presença de uma seqüência de pedículos perfurantes derivados do ramo vertical da artéria toracodorsal. Estes pedículos se localizariam em uma linha paralela à margem lateral do músculo latíssimo do dorso, cerca de 2 a $3 \mathrm{~cm}$ mediais a mesma. Três pedículos perfurantes foram descritos neste estudo. O primeiro pedículo, seria o mais calibroso e se localizaria a $8 \mathrm{~cm}$ da prega axilar. O segundo pedículo estaria 2 a $4 \mathrm{~cm}$ distal ao primeiro pedículo e seria discretamente menor. $\mathrm{O}$ terceiro pedículo seria mais fino do que os prévios e se localizaria de 2 a $4 \mathrm{~cm}$ distal ao segundo pedículo. Os dois primeiros pedículos estariam presentes em todas as 40 dissecções, e o terceiro estaria presente em 32 das 40 dissecções.

Heitmann et al (2003) realizaram um estudo anatômico com 20 cadáveres, em que todos os retalhos dissecados, os pedículos perfurantes se originavam a $8 \mathrm{~cm}$ do hilo vascular.

Guerra et al (2004) em um estudo anatômico com 20 cadáveres, encontraram o primeiro pedículo em 17 cadáveres; o segundo em 12 cadáveres e; e o terceiro em 10 cadáveres. O primeiro pedículo foi sempre mais calibroso do que o segundo ou do que o terceiro. 
O presente estudo utilizou metodologia distinta dos estudos prévios, pois somente o pedículo perfurante de maior calibre foi dissecado. Tal abordagem possui melhor correlação clínica, pois, habitualmente, o maior pedículo perfurante é escolhido como pedículo do retalho (Angrigiani et al 1995; Hamdi et al, 2004). Houve uma grande variabilidade na posição do ramo perfurante mais calibroso da artéria toracodorsal. Em um total de 21 dissecções, sua posição variou de 8 a $17 \mathrm{~cm}$ da prega axilar; e de -2 a $7 \mathrm{~cm}$ da borda do músculo latíssimo do dorso. Ao contrário de Angrigiani et al (1995), Heitmann et al (2003) e Guerra et al (2004), nem sempre o pedículo mais calibroso foi o primeiro, localizado a $8 \mathrm{~cm}$ do cavo axilar (fig. 28). Tal diferença provavelmente está relacionada à metodologia empregada.

O único parâmetro anatômico relativamente fixo foi a distância da margem do m. latíssimo do dorso. Quinze dos 21 pedículos $(71 \%)$ se localizavam em uma linha paralela, cerca de $2 \mathrm{~cm}$ medial à margem do $\mathrm{m}$. latíssimo do dorso. Tal distribuição corresponde à projeção do ramo lateral da a. toracodorsal. Este padrão é semelhante à distribuição encontrada por outros autores (Angrigiani et al, 1995; Guerra et al, 2004). Dois pedículos perfurantes, considerados de maior calibre na dissecção pertinente, se localizavam fora do $\mathrm{m}$. latíssimo dorso, com um trajeto paralelo ao mesmo. Tais pedículos correspondem ao retalho toracodorsal inicialmente descrito por Baudet et al (1976), e mais recentemente, preconizado por Kim (2005). Este achado reforça a importância da possibilidade de utilização desta variação do retalho TAP. 
A variabilidade do posicionamento da emergência do pedículo perfurante no músculo latíssimo do dorso é uma desvantagem do retalho TAP em relação ao retalho escapular, pois pode representar um aumento de tempo cirúrgico e uma maior dificuldade técnica do procedimento. Alguns autores preconizam a utilização de métodos propedêuticos auxiliares para localização do pedículo. O conhecimento desta localização facilita a dissecção do retalho e diminui o tempo cirúrgico do procedimento. O método mais comumente utilizado é o Doppler unidirecional. Alternativamente, podese utilizar o mapeamento dúplex (Taylor et al, 1990; Blondeel et al, 1998).

O Doppler unidirecional permite a identificação da projeção dos pedículos perfurantes na pele através da emissão de ondas ultrassônicas que retornam ao aparelho quando se encontram com hemácias em movimento. Trata-se de um exame não invasivo e de baixo custo. $\mathrm{O}$ tempo de exame é de cerca de 10 minutos, e pode ser realizado na própria sala cirúrgica. Aparelhos de Doppler unidirecional são portáteis e facilmente encontrados em hospitais em que haja um serviço de cirurgia vascular, pois o mesmo é utilizado para monitorização de anastomoses vasculares (Taylor et al, 1990a) (fig. 31). O mapeamento dúplex, também conhecido como Doppler bidirecional, é um exame que, apesar de possuir melhor sensibilidade e especificidade, é mais demorado e caro, além de necessitar de maior experiência por parte do examinador (Blondeel et al, 1998). 


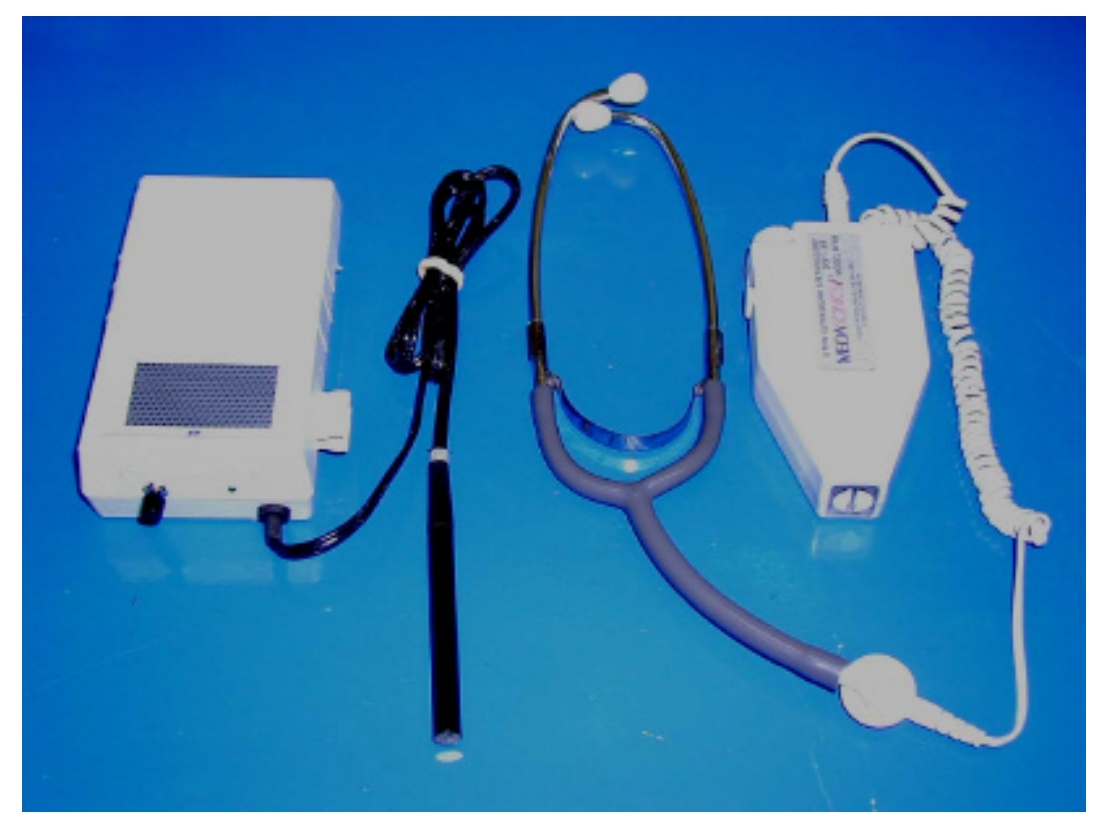

Figura 31. Aparelhos ultrassônicos de Doppler unidirecional utilizados no mapeamento de pedículos perfurantes. $O$ aparelho a esquerda possui freqüência de $10 \mathrm{mHz}$; e o aparelho a direita possui freqüência de $5,7 \mathrm{mHz}$.

O presente estudo encontrou diferenças anatômicas entre os retalhos TAP e escapular. Entretanto, outros fatores devem ser considerados no processo de escolha de um ou de outro retalho.

A dissecção do retalho TAP é tecnicamente mais difícil do que a do retalho escapular devido ao trajeto intramuscular do pedículo perfurante, que requer uma dissecção meticulosa e, muitas vezes demorada. Além disso, para que haja preservação funcional do $\mathrm{m}$. latíssimo do dorso, o nervo toracodorsal deve ser totalmente individualizado do pedículo vascular (Germann, 2004; Hamdi et al, 2004). 
Em pacientes que necessitam de reconstruções ósseas, o retalho escapular pode ser associado a um fragmento de escápula (Swartz et al, 1986). Até o momento, não existem publicações que citem a utilização do retalho TAP associado a algum retalho ósseo.

O estudo profundo da anatomia nos fornece dados que favorecem o desenvolvimento e aprimoramento das técnicas cirúrgicas. O presente estudo fornece dados importantes que distinguem anatomicamente o retalho escapular do retalho TAP. Os resultados obtidos não indicam a superioridade ou inferioridade de um ou de outro retalho, mas sim, facilitam o processo de planejamento das reconstruções, visando melhorar a compatibilidade do retalho ao defeito a ser reconstruído. 
6. Conclusões 
O presente estudo permitiu-nos concluir que:

1. O comprimento do pedículo do retalho TAP é cerca de $50 \%$ mais longo do que o comprimento do pedículo do retalho escapular.

2. O diâmetro externo da artéria toracodorsal e da artéria circunflexa escapular, imediatamente após a bifurcação da artéria subescapular, são semelhantes.

3. O diâmetro externo da veia toracodorsal e da veia circunflexa escapular, imediatamente antes da confluência na veia subescapular, são semelhantes.

4. O retalho TAP possui derme cerca de $40 \%$ mais delgada do que o retalho escapular.

5. O retalho TAP possui tecido celular subcutâneo cerca de $30 \%$ mais delgado do que o retalho escapular.

6. A localização do pedículo do retalho escapular possui localização constante, enquanto a emergência do pedículo perfurante de maior calibre do pedículo toracodorsal no território do retalho TAP possui localização variada. 
7. Anexos 


\section{AROKAGAO}

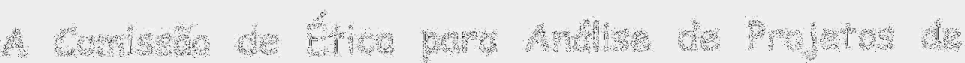

Pesquisa - CAPPesq da Diretoria Clínica do Hospital das Clínicas e da Faculdade de Medicina da Universidade de São Paulo, em sessão de 28.04.05. APROVOU o Protocolo de Pesquisa $n^{\circ}$ 265/05, intitulado: "Estudo Anatômico comparativo

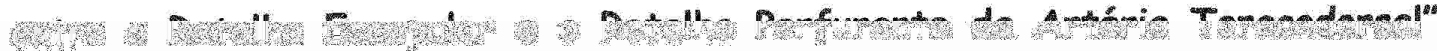

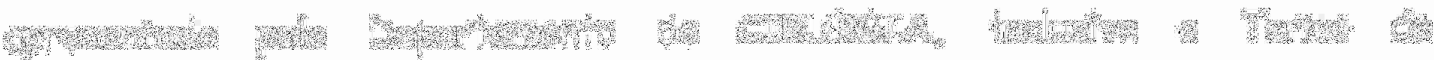
How

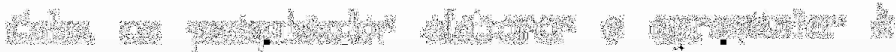

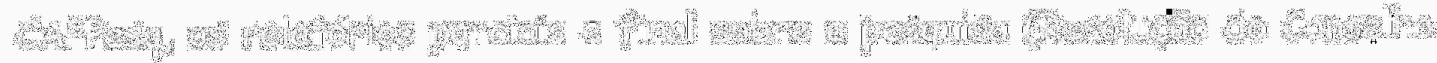

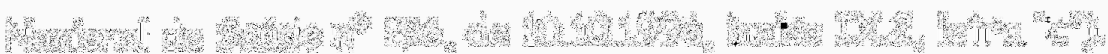

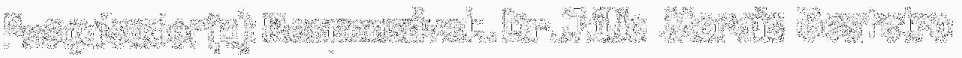

Pesquisudor(d) Executante: Br Luis Menrigue Ishida CAPpesc, 28 de aboll de 2005 .
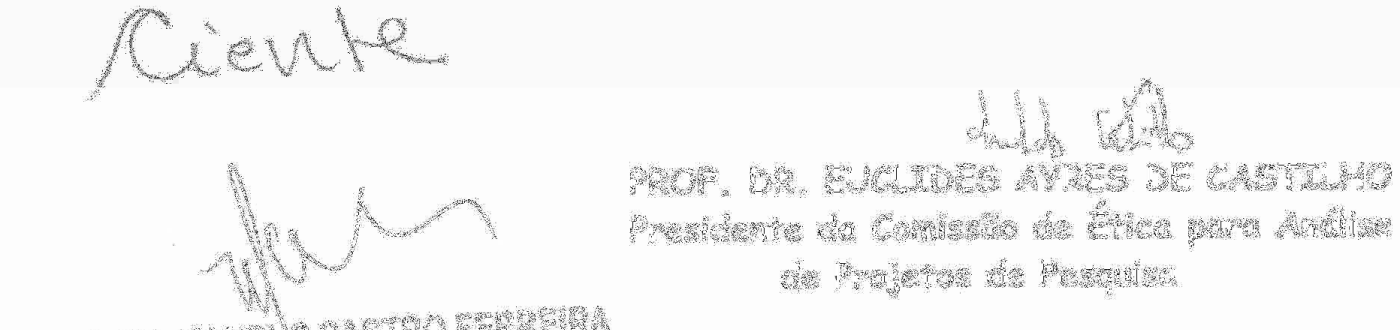

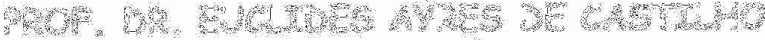
Whe Ther het

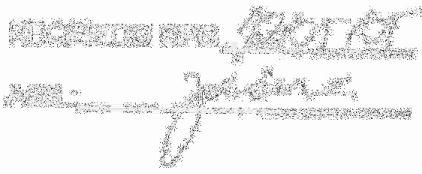

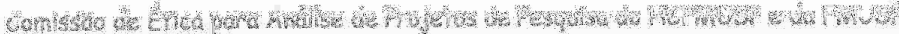

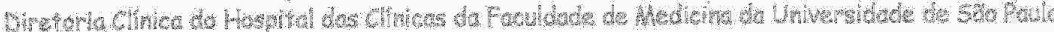

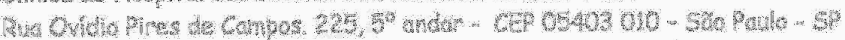

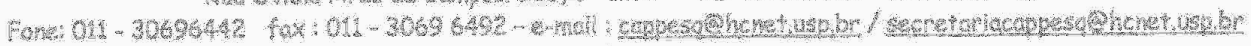


8. Referências bibliográficas 
Angrigiani C, Grilli D, Siebert J. Latissimus dorsi musculocutaneous flap without muscle. Plast Reconstr Surg 96: 1608, 1995.

Barwick WJ, Goodkind DJ, Serafin D. The free scapular flap. Plast Recontr Surg 69: 779,1982.

Baudet J, Gimberteau JC, Nascimento E. Successful clinical transfer of two free thoraco-dorsal axillary flaps. Plast Reconstr Surg 58: 680, 1976.

Blondeel PN. Vanderstraeten GG, Monstrey SJ. The donor site morbidity of the free DIEP flaps and free TRAM flaps for breast reconstructions. Br J Plast Surg 50: 322-7, 1997.

Blondeel PN et al. Doppler flowmetry in the planning of perforator flaps. Br J Plast Surg 51: 202,1998.

Bonato Jr A, Arantes HL, Henriquez SS. Retalhos fasciocutâneos. In: Mélega JM, editor. Cirurgia plástica fundamentos e arte. Rio de Janeiro: Medsi; 2002 p. 141-53.

Bostwick J, Nahai F, Wallace JG. Sixty latissímus dorsi flaps. Plast Recontr Surg 63: 31, 1979. 
Bostwick J, Vasconez LO, Jurkiewicz MJ. Breast reconstruction after radical mastectomy. Plast Reconstr Surg 61: 682, 1978.

Chen SL, Chen TM, Wang HJ. Free thoracodorsal artery perforator flap in extremity reconstruction: 12 cases. Br J Plast Surg 57: 52530, 2004.

Coleman JJ III, Sultan MR. The bipedicled osteocutaneous scapula flap: A new subscapular system free flap. Plat Reconstr Surg 87: 682, 1991.

Daniel RK, Kerrigan CL. Principles and physiology of skin flap surgery. In: McCarthy JG. Plastic Surgery: General principles. Philadelphia: W B Saunders Company; 275-328, 1990.

Dos Santos LF. The scapula flap: A new microsurgical free flap. Rev Bras Cir 70: 133, 1980.

Dos Santos LF. The vascular anatomy and dissection of the free scapula flap. Plast Reconstr Surg 73: 599, 1984. 
Germann G. The thoracodorsal artery perforator flap: Clinical experience and anatomic study with emphasis on harvest techniques [discussion]. Plast Reconstr Surg 114: 42-3, 2004.

Gilbert A, Teot L. The free scapula flap. Plast Reconstr Surg 69: $601,1982$.

Granick MS, Newton ED, Hanna DC. Scapular free flap for repair of massive lower facial composite defects. Head Neck Surg 8: 436, 1986.

Guerra AB, Metzinger SE, Lund KM, Cooper MM, Allen RJ, Dupin CL. The thoracodorsal artery perforator flap: Clinical experience and anatomic study with emphasis on harvest techniques. Plast Reconstr Surg 114: 32-41, 2004.

Hamdi M, Van Landuyt K, Monstrey S, Blondeel P. Pedicled perforator flaps in breast reconstruction: a new concept. Br J Plast Surg 57: 531-9, 2004.

Hayashi A, Maruyama Y. The reduced latissimus dorsi musculocutaneous flap. Plast Recontr Surg 84: 290, 1989. 
Heitmann C, Guerra A, Metzinger SW, Levin SL, Allen RJ. The thoracodorsal artery perforator flap: Anatomical basis and clinical application. Ann Plast Surg 51: 23, 2003.

Houaiss A, Villar MS, Franco FMM. Houaiss - Dicionário da língua portuguesa. Rio de Janeiro, Objetiva. 2003 p. 399.

Kim JT, Koo BS, Kim SK. The thin latissimus dorsi perforatorbased free flap for resurfacing. Plast Reconstr Surg 107: 374, 2001.

Kim JT. Two options for perforator flaps in the flank donor site: latissimus dorsi and thoracodorsal perforator flaps. Plast Reconstr Surg 115: 755-63, 2005.

Koshima I, Sodea S. Repair of a wide defect of the lower leg with combined scapular and paraescapular flap. Br J Plast Surg 38: 518, 1985.

Koshima I, Moriguchi T, Soeda S. The gluteal perforator based flap for repair of sacral pressure sores. Plast Reconstr Surg 91: 678, 1993.

Koshima I, Saisho H, Kawada S, Hamanaka T, Umeda N, Moriguchi T. Flow through thin latissimus dorsi perforator flap for repair of soft tissue defects in the legs. Plast Reconstr Surg 103: 1483, 1999. 
Koshima I, Soeda S. Inferior epigastric artery skin flaps without rectus abdominus muscle. Br J Plast Surg 42: 645, 1989.

Kroll SS, Rosenfield L. Perforator based flaps for low posterior midline defects. Plast Recontr Surg 81: 561, 1988.

Maruyama Y. Ascending scapular flap and its use for the treatment of axillary burn scar contracture. Br J Plast Surg 44: 97, 1991.

Mathes SJ, Nahai F. Reconstructive surgery: Principles, Anatomy \& Technique. Nova York: Churchill Livingstone; 1997.

Maxwell GP, Stueber K, Hoopes JE. A free latissimus dorsi myocutaneous flap: case report. Plast Reconstr Surg 62: 462, 1978.

Maxwell GP. Ignio Tansini and the origin of the latissimus dorsi musculocutaneous flap. Plast Reconstr Surg 65: 686, 1980.

McCraw JB. The recent history of myocutaneous flaps. Clin Plast Surg 7: 3, 1980.

Muhlbauer W, Olbrisch R. The latissimus dorsi myocutaneous flap for breast reconstruction. Chir Plast 4: 27, 1977. 
Munhoz AM. Estudo crítico da anatomia arterial do retalho vascularizado pela artéria perfurante muscular da artéria epigástrica inferior [dissertação]. São Paulo: Faculdade de Medicina, Universidade de São Paulo; 2004.

Nassif TM, Vidal L, Bovet JL, Baudet J. The parascapular flap: a new cutaneous microsurgical free flap. Plast Reconstr Surg 69: 591, 1982.

Olivari, N. The latissimus flap. Br J Plast Surg 29: 126, 1976.

Pensler JM, Parry SW. The split latissimus dorsi flap with functional preservation. Texas Medicine 82: 39, 1986.

Ponten B. The fasciocutaneous flap: Its use in soft tissue defects of the lower leg. Br J Plast Surg 34: 215, 1981.

Quillen CG, Shearin JC, Georgiade NG. Use of the latissimus dorsi myocutaneous island flap for reconstruction in the head and neck area. Plast Reconstr Surg 62:113, 1978.

Rowsell AR, Davies DM, Eisenberg N, Taylor Gl. The anatomy of the subscapular-thoracodorsal arterial system: Study of 100 cadaver dissections. Br J Plast Surg 37: 574, 1984. 
Rowsell AR, Eisenberg N, Davies DM, Taylor GI. The anatomy of the thoracodorsal artery within the latissimus dorsi muscle. Br J Plast Surg 39(2): 206-9, 1986.

Schneider W; Hill HL; Brown RG. Latissimus dorsi myocutaneous flap for breast reconstruction. Br J Plast Surg 30: 277, 1977.

Shimizu T, Ohno K, Michi K, Segawa K, Takiguchi R. Morphometric examination of the free scapular flap. Plast Recontr Surg 99: 1947-53, 1997.

Sociedade Brasileira de Anatomia. Terminologia anatômica Terminologia anatômica internacional. 1ed. São Paulo, Manole Editora, 2001. 203p.

Spinelli HM; Fink JA; Muzaffar AR; The latissimus dorsi perforator based fasciocutaneous flap. Ann Plast Surg 37: 500, 1996.

Swartz WM, Banis JC, Newton ED, Ramasastry SS, Jones NF, Acland R. The osteocutaneous scapula flap for mandibular and maxillary reconstruction. Plast Reconstr Surg 77: 530, 1986. 
Taylor GI, Daniel RK. The anatomy of several free flap donor sites. Plast Reconstr Surg 56: 243, 1975.

Taylor GI, Doyle M, McCarten G. The doppler probe for planning flaps: anatomical study and clinical applications. $\mathrm{Br} J$ Plast Surg $43: 1-16,1990 a$

Taylor GI, Palmer JH, McManamny D. The vascular territories of the body (angiosomes) and their clinical applications. In: McCarthy JG. Plastic Surgery: General principles. Philadelphia: W B Saunders Company; 329-378, 1990b

Thoma A, Heddle S. The extended free scapula flap. Br J Plast Surg 43: 709, 1990.

Thomas BP, Geddes CR, Tang M, Williams J, Morris SF. The vascular basis of the thoracodorsal artery perforator flap. Plast Reconstr Surg 116: 818-22, 2005.

Tobin GR, Moberg AW, DuBou RH, Weiner LJ, Bland KI. The split latissimus dorsi myocutaneous flap. Ann Plast Surg 7: 272, 1981. 